The Islamic city: A female interpretation

\title{
DOI: 10.20868/tf.2019.15.4001
}

\section{Narges Bazarjani *}

Fecha de Avance de tesis doctoral: 28.11.2018

Director de tesis: Javier Ruiz Sánchez

\section{Resumen}

Agar, la concubina de Abraham y la madre de la nación árabe, es la fundadora de la ciudad islámica, Meca. En la mitología islámica Agar, una vez expulsada de la tienda de Abraham y Sara, vaga desesperadamente por el desierto Paran, en busca de agua. Es entonces cuando se le aparece el arcángel Gabriel revelando le el lugar del pozo Zamzam. He aquí el origen mítico de la ciudad islámica Meca. Agar personifica las características de la nueva civilización; un lugar que sirva de refugio para una mujer esclava marginada y expulsada de la protección patriarcal.

Meca, en su origen, ha sido una ciudad femenina en el sentido deleuziano, es decir, un escenario para "devenirminoritaria", para "devenir-mujer". Pero veremos cómo la ciudad/refugio de Agar será confiscada por valores patriarcales a lo largo de la historia. Agar, la fundadora de la nación, a través del tiempo se convierte en un personaje secundario en las tres culturas abrahámicas. En este trabajo, se pretende hacer una interpretación femenina del origen de la ciudad islámica revitalizando el papel de la esclava Agar como fundadora de la nación árabe.

\section{Palabras clave}

Ciudad, ritual, devenir, cuerpo dominante, cuerpo sumiso, ciudad femenina

\section{Abstract}

Hagar, the concubine of Abraham and the mother of the Arab nation, mythically, is the founder of the Islamic city, Mecca. In Islamic mythology, Hagar, once expelled from the tent of Abraham and Sarah, wanders desperately through the Paran desert, in search of water. It is then that the archangel Gabriel appears, revealing the place of the Zamzam well, where they built the city of Mecca. Hagar embodies the features of the new civilization; a place that serves as a refuge for a slave woman marginalized and expelled from patriarchal protection.

Mecca, in its origin, has been a feminine city in the Deleuzian sense, a scene for "becoming-minority", for "becoming-woman". But we will see how the city/refuge of Hagar will be confiscated by patriarchal values throughout history. Hagar, the founder of the nation, through time becomes a secondary figure, almost forgotten, in the three Abrahamic traditions. In this investigation, we are trying to make a feminine interpretation of the origin of the Islamic city, revitalizing the role of the slave Hagar as founder of the Arab nation.

\section{Keywords}

City, ritual, becoming, dominant body, submissive body, female city

- Narges Bazarjani es alumna de postgrado del Departamento de Urbanística y Ordenación del Territorio de la Escuela Superior de Arquitectura. Universidad Politécnica de Madrid. narges.bazarjani@alumnos.upm.es. ORCID: http://orcid.org/ 0000-0002-3772-1595 
I am Hagar the immigrant,

There came to me the revelation of the water,

I left the world of Abraham, jugs sealed with cork, cooking-grease jars, Sarah's careful kitchen fires

I walked across a razor-sharp horizon, slates of earth, sediment of ancient seas to stand along at this

frontier:

Where the shape of the cup of morning is strange and dome of sky, mat of earth have shifted, Where God does not have a house yet and times of prayer have not been appointed,

Where the only water is buried deep under hard ground and I must find it or my child will die, my people remain unborn.

The firs thing the founder does is looking for water

I am Hajar [Hagar], Mother of people (Kahf, 2016:4-5)

\section{Introducción}

En este documento, intentamos arrojar luz sobre el origen mítico de la ciudad más importante y venerada del mundo islámico, la ciudad de Meca. Para este propósito, vamos a leer la vida de Agar, un personaje secundario en todas las religiones abrahámicas, cuya historia se desvanece bajo la luz intensa de la narración patriarcal de la historia. Intentaremos rastrear su figura dentro de la literatura sagrada de las religiones abrahámicas: Génesis, Corán, literatura rabínica Midrash y la tradición islámica Hadith. Nuestra intención es dibujar un mapa de su cuerpo moviéndose en las fronteras de tres culturas e ilustrar su papel fundamental perdido en la formación de la ciudad de Meca, la "Madre de las Ciudades". (Corán, 6:92 y 42: 7)

En esta investigación, veremos cómo Agar, siendo una figura significativa en la narración más temprana de la fundación de la nación árabe, se desvaneció en la sombra de Abraham e Ismael a lo largo de la historia. Cuando Muhammad aún no estaba en el poder y todavía llamaba a las clases más pobres, marginadas y vulnerables para que se unieran a él, estaba más a favor de la parte femenina de la sociedad. La primera persona que respondió a su llamado al Islam fue su esposa Khadija, una mujer rica de Meca, que lo apoyó hasta el último momento de su vida. Mientras que ella vivió, Muhammad le fue leal. Pero después de su muerte y cuando Muhammad obtuvo el poder, se convirtió en deudor de los poderosos hombres de las tribus árabes. Esta nueva situación en el sistema de poder causó el cambio radical de Muhammad hacia el sistema patriarcal establecido. La mayoría de los capítulos del Corán que están designados para la regulación/limitación de la vida/cuerpo de las mujeres, se han revelado después de que Muhammad obtuviera el poder en Medina y después del triunfo de Meca. Así también, el Islam, al igual que cualquier otro sistema de poder, regresó al sistema establecido y los primeros reclamos de apoyo a las personas vulnerables se desvanecen. En consecuencia, Agar, como una esclava expulsada y vulnerable, se convirtió en una figura secundaria en los posteriores textos escritos y orales de los musulmanes.

No obstante, según las primeras narraciones del Islam, Agar era una figura esencial en el proceso de fundación de la nación. Ella es la única figura femenina en la Biblia con quien Dios habló dos veces, y una de las pocas mujeres en la tradición islámica y el Corán, a las que Dios habló a través de su Ángel Gabriel. Las tres religiones abrahámicas la respetan y la reconocen como una mujer virtuosa. Ella fue la que recibió la revelación de la existencia de los dos pozos importantes en el antiguo Medio Oriente; Zamzam en Meca, justo al lado del templo de la Kaaba y Ber Lahai Rio entre Kadesh y Bered (Génesis, 16:14). 
Llegó al desierto de Hejaz, donde se encuentra Meca, y preparó agua para su hijo, luego trató de proteger el agua, a su hijo y a su rebaño de ovejas, trazando la primera línea de la Kaaba, la "Primera Casa de Dios" (Corán, 3:96).

Nuestra intención es trazar un mapa del cuerpo de Agar, sobrepasar las culturas y las fronteras para revivir su figura en la mitología de la urbanización en el mundo islámico. Intentamos leer la ciudad de Meca a través del papel vital de una mujer que cruza varias culturas y fronteras geográficas; una mujer cuyo ser corporal evoca fronteras, límites, regiones, geografía y civilización. Una mujer cuyo cuerpo se mueve entre las culturas islámica y judeocristiana. Su tránsito personifica el simbolismo geográfico de un cuerpo dominante así como un cuerpo rebelde de mujer esclava. Pretendemos leer la ciudad de Meca a través del mito de la expulsión de Agar y su cuerpo refugiado, mostrando su papel fundamental en la interpretación mítica de la ciudad de Meca.

\section{Marco teórico}

El orientalismo, de Edward Said, publicado en 1978 (Said, 1978), puso la noción de Islam como una entidad pública en el centro de muchos nuevos debates académicos. Said trató de atraer la atención hacia una noción abierta del Islam lejos de ser una "entidad cultural encerrada" (Rahimi, 2012). En su opinión, el Islam es o, mejor dicho, "Ios Islames" son híbridos complejos que se convierten en situaciones que difieren según los contextos. Puede ser oportuno aquí citar la afirmación de Aziz Al-Azmeh de que "hay tantos Islames como situaciones que los sostienen" (AlAzmeh, 1993:1). Esta variedad de Islames debe surgir de diversos contextos espacio-temporales; del mismo modo, esta diversidad del Islam debería generar muchos contextos diferentes y diversos de la esfera pública y de la privada. Por lo tanto, hablar de mundo musulmán, urbanidad musulmana, espacio público musulmán o cultura musulmana como una subjetividad singular sería un discurso falso.

Por otra parte, la noción de espacio y espacio público adoptada aquí, como el autor ha analizado en otro texto (Bazarjani, 2016:24), es una entidad abierta, en construcción, múltiple y heterogénea. Doreen Massey lo explica como "un devenir continuo, que es la naturaleza del ser [...] un producto abierto y siempre en proceso" (Massey, 2005: 13). Es una entidad híbrida multidimensional, siempre en formación, a través de interrelaciones sociales de múltiples capas. El espacio es un resultado inacabado de una interactividad social constante. El concepto de espacio está estrictamente vinculado a la interrelación social, que también incluye la construcción social de género; posteriormente, nuestra comprensión de la espacialidad se debe vincular rigurosamente a la concepción de género y al proceso de formación social de género.

"Si Dios es masculino, entonces el hombre es Dios" (Daly, 1973: 19) es la sorprendente afirmación de Mary Daly en su libro Más allá de Dios Padre. Daly se opuso a la imagen masculina predominante adjudicada a Dios en las tradiciones abrahámicas; una imagen que da lugar a una sociedad patriarcal en la cual las mujeres se multiplican en desventaja, maltratadas o ignoradas. Rechazar una imagen masculina de la deidad da lugar a la necesidad de re-leer nuestra "imagen del mundo" (Weber, 1946: 280), la imagen de la que hemos partido. Existe la necesidad de ir al origen, para re-leer y re-narrar nuestra "imagen del mundo", fuera de los valores patriarcales dominantes.

Se hace preciso re-narrar la formación de una ciudad islámica primitiva, a través de una conciencia femenina de sus orígenes míticos. A lo largo de esta interpretación mítica de los textos originales, tratamos de hacer que la figura periférica de Agar sea más central de lo que ha sido 
percibida convencionalmente por la lectura masculina de los textos canónicos. En esta lectura interpretativa e intercultural de la vida de Agar, nos hemos centrado en su lucha corporal para encontrar agua para su hijo, que se ha convertido en el ritual anual del Haj.

El ritual, como proceso tanto comunicativo como performativo, deja espacio para la manifestación tanto del cuerpo dominado como del cuerpo rebelde. Es en este espacio, enmarcado por el ritual, donde se manifiestan tanto la personificación del poder, como la resistencia del dominado. El ritual crea un marco cognitivo a través del cual el lugar se llenará de significado. El ritual, como medio de expresión y subordinación, da forma a nuestra conciencia del espacio, tanto secular como religioso. Como David E. Apter menciona en su artículo, La política como teatro, "una buena representación teatral permitirá la personalización" (Apter, 2006: 225). El ritual en este sentido es un teatro político puro que crea escenarios para el intercambio constante de roles. Siguiendo el punto de vista de Apter, en nuestro caso, el ritual del Hajj incluye la preparación del sitio, puesta en escena, ambientación, localización, arquitectura, decoración y todo tipo de artes espaciales, para generar la sacralización y la hierofanía (Eliade, 1959).

El ritual otorga a lo ordinario lo excepcional y toma la vida cotidiana de las personas para trascenderla a una entidad pública y coral. Siguiendo a Apter, tratamos de mostrar cómo las personas, desempeñan su propio papel en el drama público de Hajj, se sienten privilegiadas y elegidas "para disfrutar de la excepcionalidad" (Apter, 2006: 249). El ritual, como un dispositivo excepcional, es capaz de codificar sus significados específicos espaciales e imponerles una dimensión sagrada y un simbolismo semiótico. En el propósito de enmarcar el espacio para este drama político y convertirlo en un espacio semiótico, el ritual es el dispositivo principal para vaciar el lugar del conocimiento convencional y rellenarlo con nuevos signos y símbolos referenciales al servicio del mensaje necesario. La ciudad de Meca, el sitio del ritual, fundada por la lucha corporal de una mujer exiliada, marginada y esclava, es un terreno semiótico dotado para la manifestación de lo sagrado.

\section{Metodología}

El método por el que optamos para elaborar esta investigación adopta un enfoque hermenéutico interpretativo de los textos canónicos y las narraciones tradicionales de las religiones abrahámicas. El método aplicado consiste en encontrar la conexión de narraciones y textos míticos de diferentes culturas, para visibilizar una historia femenina, cuya voz ha sido silenciada por la hegemonía de la interpretación falocéntrica del tiempo y el espacio. Nuestra intención final es renarrar la ciudad islámica, específicamente la ciudad de Meca, en un contexto femenino, reivindicando a la figura fundamental de Agar.

La ciudad de Meca no se podía leer ignorando sus orígenes míticos. En este texto, tratamos de remarcar el rastro de lo sagrado mitológico en el paisaje urbano de Meca. Cada ciudad es mucho más que una aglomeración de edificios, infraestructuras y espacios cartesianos. Más allá de cada ciudad visible, cristalizada e incrustada en materiales, la urbanidad tiene un origen mítico. Desde las antiguas sociedades agrícolas hasta nuestras modernas ciudades capitalistas, siempre ha habido mitos detrás de la construcción y el impulso de una ciudad. Si recordamos la afirmación de Levi Strauss sobre el mito: "es imposible entender un mito como una secuencia continua", aquí estamos tratando de entender la ciudad, al igual que si leyéramos un mito, es decir, "Más o menos como leeríamos una partitura de orquesta" con una "reconstrucción continua" de significados y eventos. (Lévi-Strauss, 2013: 20) 
Por otra parte, es necesario explicar que nuestra intención no es ofrecer una historia completa de la ciudad de Meca o de la vida de Agar. Más bien, el fundamento metodológico que aplicamos es un método que conecta narraciones míticas y teológicas fragmentadas, con el objetivo de producir una interpretación hermenéutica del espacio público, en la comprensión islámica del universo.

Estamos releyendo la vida de Agar, su huida de su patriarca, su alianza con Abraham y Sara y nuevamente su rebelión contra el nuevo Patriarca. Se trata del proceso que pasó Agar en su devenir, de acuerdo con la idea de Deleuze y Guattari alrededor de "devenir-mujer" y "devenirminoritario" (Deleuze \& Guattari, 1987). Al plantear esta perspectiva relacionada con el tema, tratamos de enfatizar cómo una re-narración femenina de la historia es crucialmente necesaria, porque "no hay historia sino de la mayoría, o de las minorías según se definen en relación con la mayoría" (Deleuze \& Guattari, 1987: 292).

El pasado es una metáfora imaginada de imágenes fragmentadas de la historia, en contextos específicos de espacio-tiempo. "[La] noción de una imagen no se refiere a la idea de una representación verdadera/auténtica del mundo" (D'Andrea, 2011: 91), sino que nuestra imagen del mundo, en una comprensión weberiana, es una imagen fragmentada. La realidad es el resultado de una construcción humana. Aquí estamos tratando de recuperar recuerdos inconscientes de un pasado mítico para re-encuadrar y re-codificar una "imagen del mundo" en el contexto del esquema islámico del universo, más allá de la consideración masculina del espacio. Tratamos de volver a encuadrar una narrativa distinta, de un espacio público múltiple e híbrido, en el contexto de un proceso transcultural, multidisciplinario y multidireccional de fuentes primarias y textos canónicos.

\section{Meca contemporánea}

Meca es la ciudad más sagrada del universo, según los musulmanes. Esta ciudad, desde que ha sido documentada, se sabe que ha vivido económicamente a base de un turismo masivo atraído por su santidad. Todo se organiza en función de los rituales designados a su santuario Kaaba, que según los musulmanes es la "Primera Casa de Dios" (Corán, 3:96).

Según la tradición oral de los musulmanes y la narración del profeta Muhammad, el primer santuario de Kaaba fue construido por Adán y Eva, este edificio desapareció debido al diluvio en la era de Noé. Más tarde, Abraham, Agar e Ismael lo reconstruyeron en el mismo lugar. Y por mandato de Dios, Abraham revitalizó el mismo ritual que Adán y Eva solían realizar para venerar el santuario. Antes de la época de Muhammad, los paganos de Meca solían realizar el mismo ritual para venerar a sus ídolos de piedra. El Dios de Muhammad también revalidó el ritual del Hajj y ordenó a los musulmanes de todo el mundo que realizaran el Hajj una vez en la vida si eran capaces física y económicamente.

En consecuencia, en Meca moderna, el hilo conductor de cualquier intervención, en la antigua ciudad de Meca, está dispuesto para facilitar este ritual anual. La ciudad de Meca hoy en día es la ciudad más cerrada del mundo. La ciudad no tiene ningún aeropuerto internacional ni vuelo directo desde el extranjero. Los no musulmanes tienen acceso limitado para entrar. Las personas que no son de Meca solo pueden entrar a la ciudad sagrada y prohibida, para participar en el ritual del Hajj. Un peregrino musulmán tendrá cinco puntos fijos de llegada en arabia saudí, llamados Miqats. Desde ellos será transferido al escenario sagrado. 
Meca nunca ha sido la capital de ningún régimen islámico, ya que durante la vida del profeta Muhammad, la segunda ciudad santa de los musulmanes, Medina, fue el centro político. Después de la expansión del reinado islámico y de las dinastías Umayyad (661-750 dC) y Abbasid (7501258) respectivamente, Damasco y Bagdad reemplazaron a Medina. En el apogeo del poder del Islam, Meca ha estado políticamente bajo la sombra de grandes ciudades como Damasco, Bagdad, El Cairo, Estambul e Isfahan. Meca, a lo largo de la historia del islam, morfológicamente siguió siendo una ciudad provinciana, que antitéticamente iba a albergar todos los años, durante el mes del Hajj, masas de peregrinos de todo el mundo. (Bianca, 2000: 222)

Después de la Segunda Guerra Mundial, a mediados del siglo XX, la mejora de los sistemas de aeronaves y la disminución relativa de los precios de los vuelos todavía llevaron a un aumento más drástico en el número de peregrinos. En las peregrinaciones recientes, el número de visitantes supera los dos millones, lo que da lugar a una crisis de vivienda, sanidad, seguridad y transporte.

La distribución temporal dramática de los peregrinos se manifiesta en el paisaje urbano. Las estructuras principales de la ciudad giran en torno a cuatro lugares sagrados principales: Kaaba, Mina, Mashar y Arafat. La ciudad se estructura en varios centros comerciales, alojamiento comercial de peregrinos estacionales, autopistas urbanas, aparcamientos de varios pisos y túneles para el transporte masivo entre los escenarios del Hajj "Figura 1 y 2". La mayoría de los tejidos históricos de la ciudad han sido demolidos debido a tres inmensas expansiones de Haram durante los años 60 y 70, para dar lugar a los hoteles y centros comerciales. La expansión del santuario y la construcción masiva de anillos de autopistas a su alrededor obligaron a la expulsión de los distritos residenciales de la ciudad vieja.

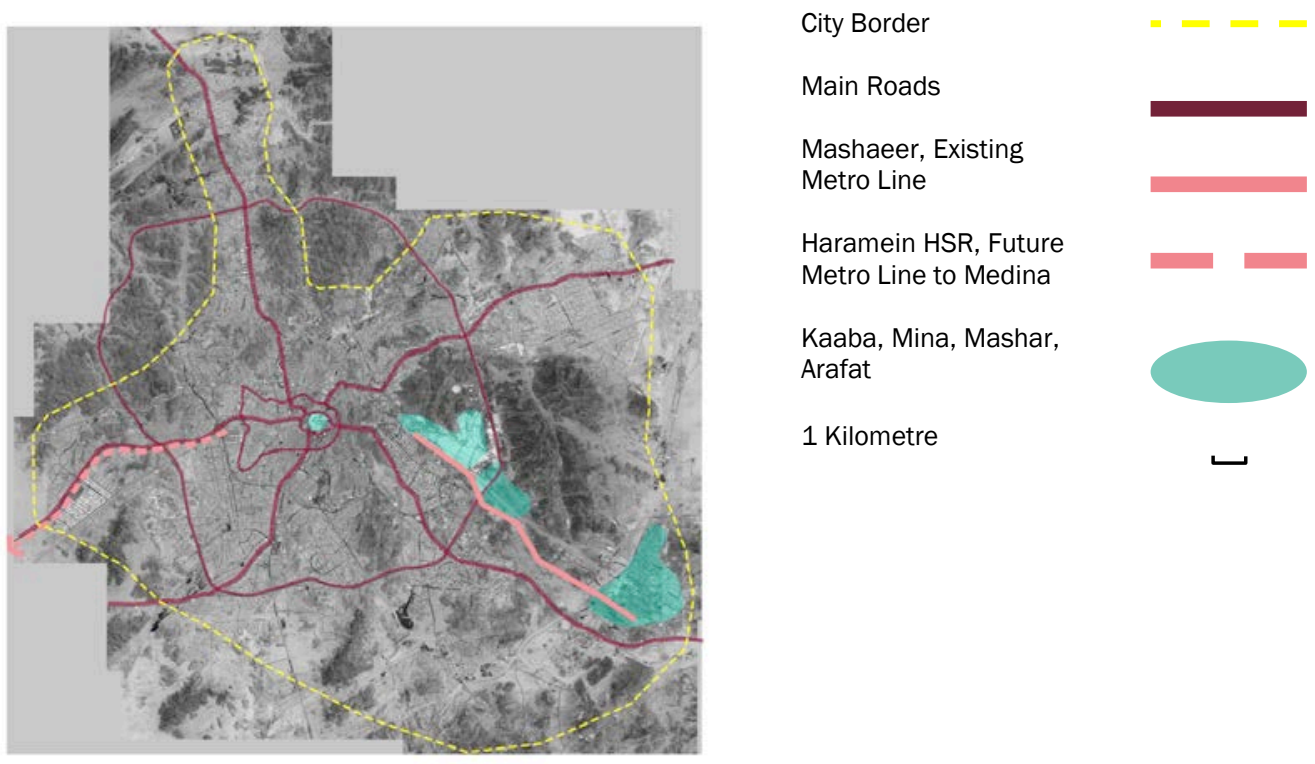

Figura 1. Mapa de la comunicación, en área metropolitana de Meca Fuente: Elaboración propia 


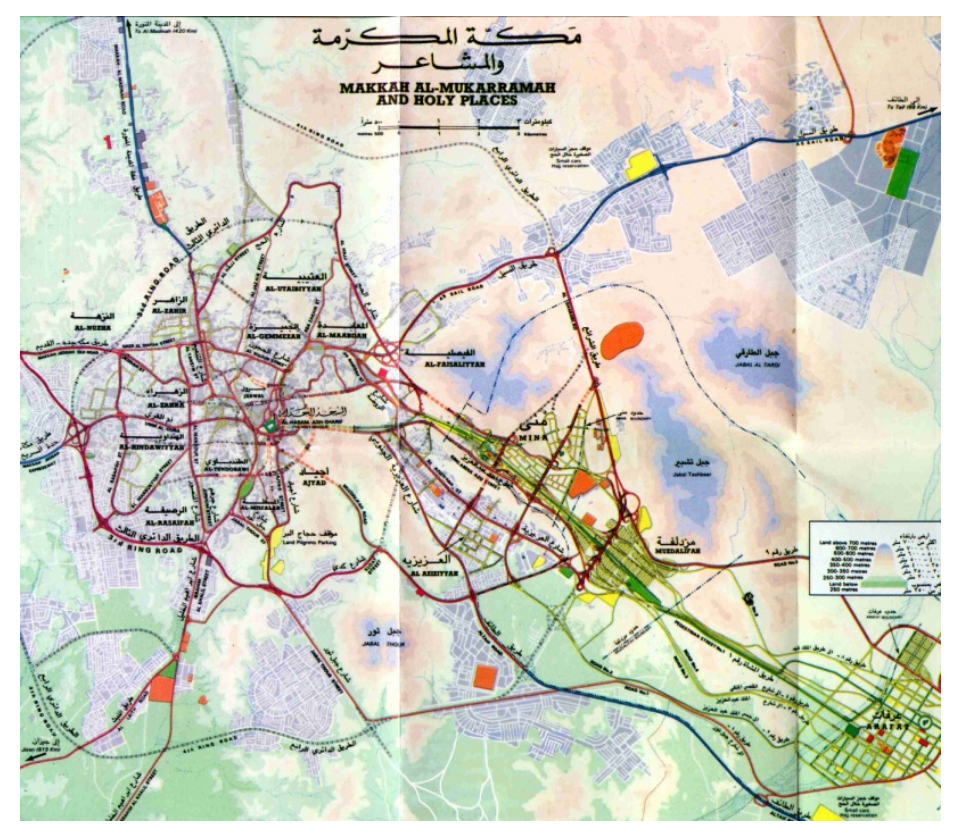

Figura 2. Mapa de Meca

Fuente: Hajj Authorities

\section{Leyendo a Agar a través de la literatura judeo-cristiana}

Y Sarai, esposa de Abram, no le daba hijos; y ella tenía una sierva egipcia que se llamaba Agar. Dijo, pues, Sarai a Abram: Ya ves que Jehová me ha hecho estéril; te ruego que te allegues a mi sierva; quizá tendré hijos de ella. Y atendió Abram a la voz de Sarai. Y Sarai, esposa de Abram, tomó a Agar, su sierva egipcia, al cabo de diez años que había habitado Abram en la tierra de Canaán, y la dio a Abram, su marido, por esposa. Y él se allegó a Agar, la cual concibió. (Génesis, 16:1-4) "Figura 3"

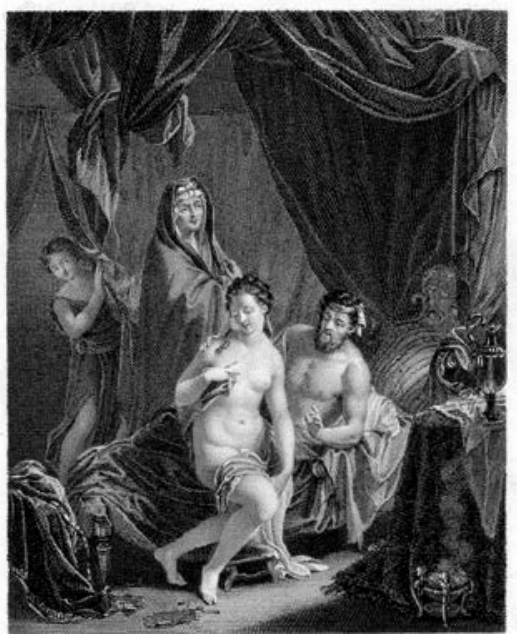

Figura 3. Hagar received by Abraham. Agar recue par Abraham. Engraved by Jean Massard, Dediée à la Reine. Paris Jean Massard After Phillip van Dyk, Massard, now in the Louvre, Paris, 1785

Fuente: Snowbound, 2001 
Agar, según la literatura rabínica Midrash, la tradición cristiana y las tradiciones orales islámicas Hadith, era una princesa egipcia. Su nombre, según diferentes referencias, significa: Vuelo, Fugitiva, Extranjera, Extraña, Regalada, Recompensada, Inmigrante. Y al mismo tiempo, Agar también significa la Ciudad.

La mítica historia de su vida está entretejida con todas las religiones abrahámicas. En el Génesis podemos rastrear su papel secundario como concubina de Abraham, el padre de la nación. A pesar de haber nacido en Egipto, su historia se remonta a la historia de la huida de Abraham de su tierra natal, Ur, para difundir la fe de Dios sobre la tierra. Los arqueólogos han rastreado el origen de la tribu de Abraham, Habiru o Hebreos, en la región de Sumer, alrededor del 2000 a.C. (Fiero, 2015: 30). Las narraciones bíblicas e islámicas afirman que Abraham, por mandato de Dios, trasladó a su tribu desde Ur, la ciudad mesopotámica, hacia el oeste a través de la Creciente Fértil para establecerse en Canaán.

Ahora bien, Jehová había dicho a Abram: Vete de tu tierra, y de tu parentela y de la casa de tu padre, a la tierra que te mostraré; (Génesis, 12:1)

Y pasó Abram por aquella tierra hasta el lugar de Siquem, hasta el valle de More; y el cananeo estaba entonces en la tierra. Y se apareció Jehová a Abram y le dijo: A tu descendencia daré esta tierra. Y edificó allí un altar a Jehová, quien se le había aparecido. (Génesis, 12:6-7)

Lot creyó en él y dijo: "En verdad, soy un emigrante hacia mi Señor. En verdad, Él es el Poderoso, el Sabio." (Corán, 29:26)

Después de unos años, alrededor del año 1700 a.C., debido a una gran hambruna en Canaán, Abraham y su gente se refugiaron en Egipto. Allí los recibió el faraón.

Y hubo hambre en la tierra, y descendió Abram a Egipto para morar allá, porque era grande el hambre en la tierra. (Génesis, 12:10)

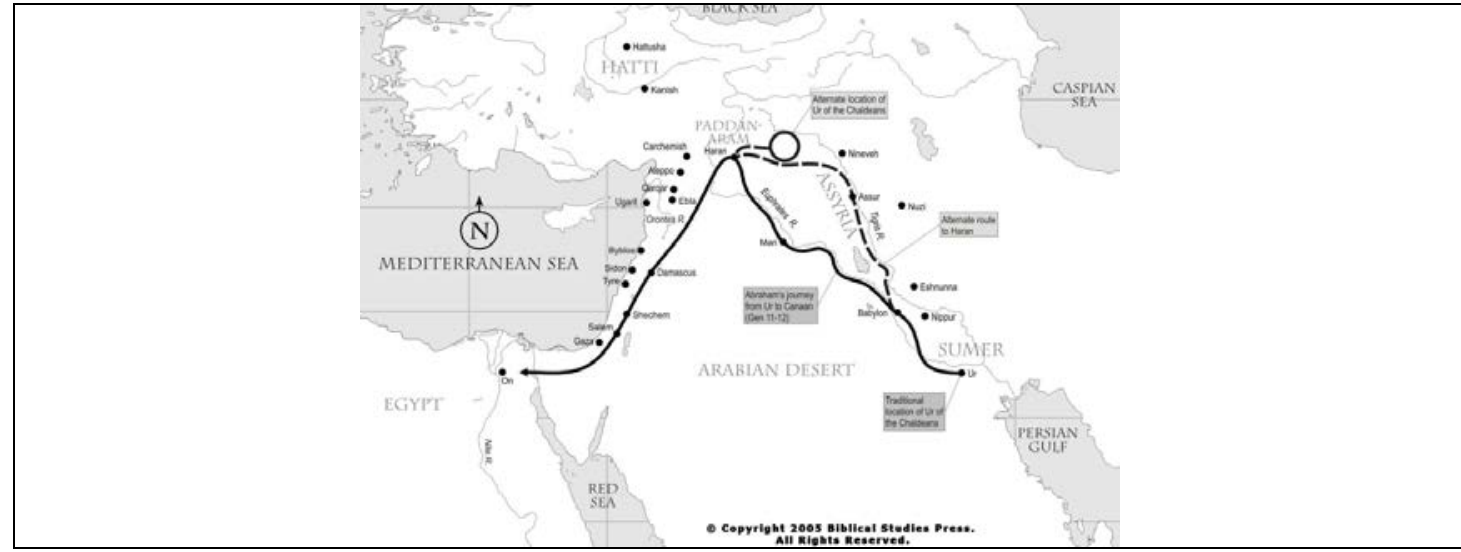

Figura 4. Abraham's Journey from Mesopotamia

Fuente: Biblical Studies Press, 2005

En Egipto, de acuerdo con las tradiciones orales judías y cristianas, Agar, la hija de Faraón, se apegó tanto a Sarai, la matriarca de los judíos, que le dijo a su padre que ella abandonaría su tierra natal con Sarai y Abram. 
"iQué!", Exclamó el rey, "no serás más que una sierva para ella". "Mejor ser una sierva en las tiendas de Abraham que una princesa en este palacio", dice Agar. (Lockyer, 1967:61)

Agar, la chica rebelde, huye de su tierra natal, de sus deidades y de sus patriarcas para refugiarse en una nueva tierra y adorar a un dios extranjero. Pero la profecía de su padre se hizo realidad y Sarai la trató como a su esclava. Y de conformidad con la ley de Hammurabi, que era válida en el momento entre los clanes de la región, Sarai regaló a Abram a su sierva Agar para que le diera el hijo prometido, que ella no había podido engendrar.

Caso que un hombre haya tomado (por esposa) a una (sacerdotisa) naditum y esa naditum le haya ofrecido una esclava a su marido y ella le haya hecho tener hijos, si luego ese hombre se propone tomar (¿por concubina?) a una shugitum [por la esterilidad de la esposa], que no se lo concedan a ese hombre; no tomará a la shugitum. (Código de Hammurabi, 144)

Pero después de estar embarazada, Agar se encontró en una situación más segura que una esclava y se manifestó como la chica rebelde que era. Cuando surgieron tensiones entre la amante y su esclava, Agar huyó, desesperada, hacia el desierto y se sentó cerca de un pozo entre Kadesh y Bered, al lado del camino hacia Shur. Ella estaba Ilorando amargamente cuando el ángel de Dios se le apareció:

Y le dijo: Agar, sierva de Sarai, ¿de dónde vienes tú y a dónde vas? Y ella respondió: Huyo de delante de Sarai, mi señora. Y le dijo el ángel de Jehová: Vuélvete a tu señora y ponte sumisa bajo su mano. Le dijo también el ángel de Jehová: Multiplicaré tanto tu linaje que no se podrá contar a causa de la multitud. (Génesis, 16:8-10)

Agar se complace en "haber sido vista por Dios" (Génesis, 16:13) y por su Ángel en su momento más oscuro. Y llamó al pozo Ber Lahai Rio: Pozo del viviente que me ve. (Es el lugar cerca del cual Isaac se asentó después de la muerte de Abraham).

Agar regresó con sus amos y dio a luz al hijo de Abram, Ismael; "A quien Dios escucha" (Génesis, 16:11). Pero después de un tiempo, la promesa de Dios se hizo realidad y Sarai dio a luz a Isaac, "El que ríe" (Génesis, 17:19), el hijo de la promesa. Él, de nuevo según los códigos de Hammurabi, es considerado el heredero legítimo de su padre.

Ahora bien, si el padre, en vida, no les declara a los hijos que le haya alumbrado la esclava: "Sois hijos míos", que, cuando al padre le haya llegado su última hora, los hijos de la esclava no hagan partes iguales de los bienes de la casa del padre con los hijos de la esposa principal; se efectuará la puesta en libertad de la esclava y de sus hijos: los hijos de la esposa principal no les exigirán a los hijos de la esclava su vuelta a la esclavitud. (Código de Hammurabi, 171)

Así que Sara1, temiendo que Ismael pudiera arrebatar la herencia de su hijo Isaac, le pidió a Abraham que expulsara a Agar y a su hijo.

1 Cuando Dios evangelizó el nacimiento de Isaac, le ordenó a Abram que "ya no vas a llamarte Abram, sino Abraham" (Génesis, 17:5) y también "De ahora en adelante tu esposa ya no se llamará Sarai; su nombre será Sara." (Génesis, 17:15). 
Por tanto, dijo a Abraham: Echa a esta sierva y a su hijo, porque el hijo de esta sierva no ha de heredar con mi hijo Isaac. Este asunto le pareció grave en gran manera a Abraham a causa de su hijo. Entonces dijo Dios a Abraham: No te parezca grave el asunto a causa del muchacho ni de tu sierva; en todo lo que te diga Sara, oye su voz, porque en Isaac te será llamada descendencia. Y también del hijo de la sierva haré una nación, porque es tu simiente. Entonces Abraham se levantó muy de mañana, y tomó pan, y un odre de agua y se lo dio a Agar, poniéndolo sobre su hombro, y le entregó el muchacho y la despidió. Y ella partió y anduvo errante por el desierto de Beerseba. (Génesis, 21:10-14) "Figura 5"

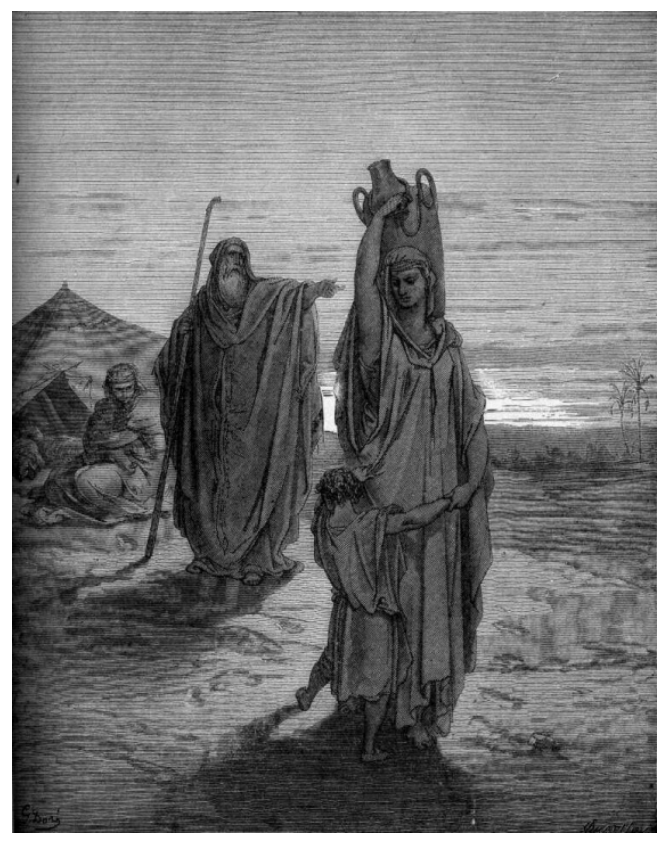

Figura 5. The Expulsion of Hagar

Fuente: The Doré Gallery of Bible Illustrations, 2014

Agar e Ismael vagaron por el desierto de Beerseba "Pozo del juramento" (Génesis, 21:31) y cuando se quedaron sin agua, nuevamente el Ángel de Dios la llamó:

Y oyó Dios la voz del muchacho, y el ángel de Dios llamó a Agar desde el cielo y le dijo: ¿Qué tienes, Agar? No temas, porque Dios ha oído la voz del muchacho en donde está. Levántate, alza al muchacho y sostenle de la mano, porque haré de él una gran nación. Entonces le abrió Dios los ojos, y vio un pozo de agua; y fue y llenó el odre de agua y dio de beber al muchacho. (Génesis, 21:17-19)

El Génesis dice que el niño y su madre se establecieron en el desierto de Paran y Agar le consiguió una esposa de Egipto, su tierra de origen. El Génesis ya no menciona a Agar, excepto una vez más: "Y Abraham tomó otra esposa, cuyo nombre era Cetura" (Génesis, 25:1). Algunas tradiciones rabínicas identifican a Cetura como Agar y afirman que después de la muerte de Sara, Isaac hace que Abraham y Agar se unan de nuevo. El nombre de Cetura, que significa "atadura", se concede a Agar debido a su lealtad a Abraham. 
Por otro lado, el apóstol Pablo afirma que Agar y su hijo Ismael representan al Monte Sinaí y la esclavitud, y Sara y su hijo Isaac representan a Jerusalén, ciudad celestial, como seres libres.

Estos dos casos pueden servirnos de ejemplo. Las dos mujeres representan dos pactos. Agar representa el pacto del monte Sinaí, que está en Arabia, pues todos sus descendientes nacen siendo esclavos. Ese monte representa a la ciudad de Jerusalén y a todos los que viven como esclavos de la ley. Pero Sara representa al nuevo pacto, por el cual pertenecemos a la Jerusalén del cielo, la ciudad de todos los que somos libres. (Gálatas, 4:24-26)

También San Pablo describe a Ismael como un nacimiento puramente carnal, al contrario de Isaac, que nació por el poder del espíritu. De esta forma, invoca a la Biblia para enfrentar a dos hermanos y, consecuentemente, a los esclavos y a los hombres libres.

Pero la Biblia nos cuenta que Dios le dijo a Abraham: "Echa de aquí a esa esclava y a su hijo; él no tiene derecho a compartir la herencia con tu hijo Isaac, que nació de una mujer libre." Hermanos, nosotros no somos esclavos de la ley, sino que somos libres. No somos como el hijo de la esclava, sino como el de la mujer libre. (Gálatas, 4:30-31)

Del mismo modo, San Agustín en el libro La ciudad de Dios, refiriéndose a San Pablo, simboliza a Agar como una "ciudad terrena" y a Sara como una "ciudad libre".

Una parte, en efecto, de la ciudad terrena ha resultado imagen de la ciudad celeste, no significándose a sí misma, sino a la otra, y, por ello, haciendo de esclava. Pues no fue ella la razón de su fundación, sino el significar a la otra, aunque también la misma ciudad que prefigura fue prefigurada por una imagen anterior. Agar, en efecto, la esclava de Sara, y su hijo fueron como una imagen de la otra imagen. Y como habían de pasar las sombras con la llegada de la luz, por eso dijo la libre Sara, imagen de la ciudad libre, a la que también significaba de otro modo aquella sombra: Expulsa a esa esclava y a su hijo, porque el hijo de esa criada no va a repartirse la herencia con mi hijo Isaac, o con el hijo de la libre, que dice el Apóstol. (San Agustín, Libro XV, Capítulo II)

El viaje de Agar comienza escapando de su patria, Egipto. Se refugió en la tienda de Abraham, donde fue tratada como esclava y se convirtió en la concubina de Abraham. En esta lucha de úteros en la antigua sociedad patriarcal, la esclava Agar perdió ante Sara, la mujer libre. Sara y Abraham la expulsaron de su refugio y la empujaron al desierto de Paran. El Génesis deja la historia de Agar en el desierto de Paran. Sin embargo, los musulmanes continuaron su historia y basaron su origen en su cuerpo refugiado expulsado de la cultura judeocristiana.

\section{Leyendo a Agar a través de la literatura islámica}

Juro por esta ciudad [Meca], por esta ciudad en la que tú [Muhammad] resides, y por un padre [Abraham] y lo que engendra: Ciertamente, hemos creado al ser humano en el esfuerzo y el cansancio. ¿Cree que nadie tiene poder sobre él? Dice: "iHe derrochado una gran fortuna!" ¿Cree que nadie le ve? ¿Acaso no le hemos puesto dos ojos? ¿Y una lengua y dos labios? ¿Y no le hemos indicado las dos vías? Sin embargo no se apresura a subir la cuesta. ¿Y qué te hará saber lo que es la cuesta? Es liberar a un esclavo. (Corán, 90:1-13) 
En las creencias y tradiciones islámicas de los árabes, el mito de Agar se ha transmutado a un nivel épico. Para los musulmanes, la expulsada Agar, como madre de la nación, encarna una larga historia de dura lucha en la dura e inflexible condición de la Península Arábiga; su lucha personifica una larga historia de batalla humana para sobrevivir.

El Corán no indica el nombre de Agar pero, según la mayoría de las tradiciones islámicas, se menciona implícitamente en el Capítulo 14 del Corán. (Firuzabadi, 1992)

"iSeñor nuestro! En verdad, he asentado a parte de mi descendencia [Agar e Ismael] en un valle desierto, junto a Tu Casa Sagrada ¡Señor nuestro! para que hagan la oración. ¡Haz, pues, que los corazones de la gente se vuelvan hacia ellos y provéeles de frutos para que sean agradecidos!’ (Corán, 14:37)

Sin embargo, Hadith y Tafsir islámicos, van más allá de esta breve mención implícita en el Corán. Según fuentes islámicas, el desierto de Paran, mencionado en el Génesis, es el mismo desierto de Faran, que es un antiguo nombre de Hejaz, la provincia de Arabia Saudita donde se encuentra la ciudad de Meca. (Firestone, 1992, 5-24)

En la narración islámica, Abraham instaló a Agar y a su amado hijo, Ismael, en el lugar sagrado de Kaaba en el desierto de Paran/Faran/Hijaz, cerca de las montañas de Meca, más allá de Siria y Aylah (el antiguo nombre de Aqaba en el Jordán de hoy). (Khaldun, 1958, 51)

Abraham los dejó a la sombra de un árbol con algo de agua y comida y regresó a su tribu. Ismael y su madre se quedaron sin agua y Agar dejó a su hijo en el centro del valle donde ella podría observarlo mientras trepaba alternativamente a las dos montañas cercanas, Safa y Marwa, en busca de agua. Cuando asciende a Safa y mira hacia atrás ve un espejismo. Desciende corriendo hacia el y asciende a la montaña opuesta, Marwa. Repitió su amarga lucha desesperadamente siete veces hasta que escuchó la voz del Ángel de Dios, Gabriel "Figura 6".

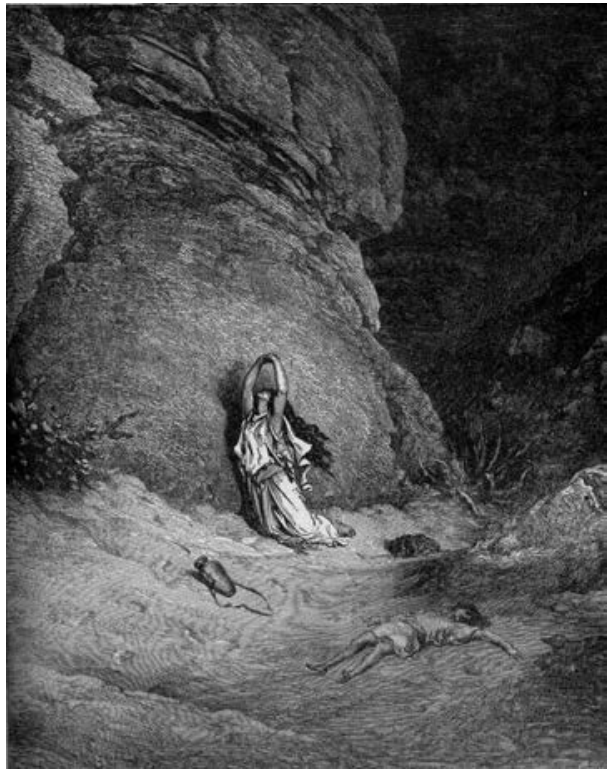

Figura 6. Hagar and Ishmael in the Wilderness Fuente: The Doré Gallery of Bible Illustrations, 2014 
Escuchó un sonido y se dijo a sí misma: "Tranquila". Volvió a escuchar el sonido, y luego dijo: "Te he escuchado. Ayúdame, si puedes". De repente, encontró un ángel en el lugar donde ahora está [el pozo de] Zamzam. Lo cavó con el talón o lo tocó (el suelo) con su ala y apareció un manantial. Hajar [Agar] rodeó el agua con tierra. Tomó un poco de agua en un recipiente y el agua seguía burbujeando en el pozo". (Firuzabadi, 1992)

Dios les proporcionó agua al revelar el pozo de Zamzam y provocó que una tribu llamada jurhumitas pasara por este lugar, habitara alrededor del pozo y acogiera a Agar e Ismael.

Las tradiciones islámicas justifican el derrocamiento de Agar por parte de Abraham como otra prueba divina (aparte de estar obligado por Dios a sacrificar a su hijo Ismael). Los musulmanes afirman que el objetivo del viaje de Agar fue establecer una nueva civilización y no expulsar a la madre de su hijo.

Agar y su hijo habitaban en el desierto de Hijaz y acceptan a los jurhumitas para formar una nueva civilización, una civilización engendrada por una esclava, marginada y expulsada. La historia del lugar más sagrado de la cultura musulmana, la ciudad de Meca, surge sobre la base de la precaria condición exílica de esta mujer legendaria, una figura siempre transmutable que siempre se ha movido entre las periferias y los centros.

\section{La fundación de la Umm al-Qura (Madre de las ciudades)}

Ésta es una Escritura bendita que Nosotros hemos hecho descender confirmando lo que ellos tienen en sus manos, para que adviertas a la Madre de las Ciudades [Meca] y a quienes viven en sus alrededores. $Y$, quienes creen en la otra vida, creen en ella y son cuidadosos de sus oraciones. (Corán, 6:92)

$Y$, así mismo, te hemos revelado un Corán árabe para que amonestes a la madre de las ciudades y a quienes están alrededor de ella y amonestes sobre el Día de la Reunión, sobre el que no hay duda. Un grupo estará en el Jardín y otro grupo estará en el Fuego Ilameante. (Corán, 42:72)

Agar e Ismael construyeron un círculo rodeado de un seto de palmas alrededor de pozo Zamzam para albergar a sus ovejas y cabras. Abraham los visitó varias veces y en su última visita, Dios le ordenó construir Kaaba en el sitio. Permitieron a los jurhumitas vivir allí y formaron el oasis de Meca junto a la santa Kaaba.

Históricamente, sabemos muy poco sobre el origen de la ciudad de Meca, pero al leer los textos religiosos más antiguos, podemos rastrear los orígenes míticos de la ciudad. Por otra parte, hay algunas breves menciones a Meca y a su santuario en los textos de los primeros viajeros e historiadores de Medio Oriente, como Claudio Ptolomeo y Diodoro Sículo. Pero mitológicamente su fundamento está asociado con la creación del ser humano.

Refiriéndose a las declaraciones de los escritores griegos sobre un gran santuario árabe en Meca Kaaba, el santuario fue construido en el siglo VI a.C. (Margoliouth, 2003: 8) La ciudad de Meca y el santuario también han sido mencionados por Claudio Ptolomeo (el geógrafo grecorromano del siglo II), llamándola Makoraba, como un santuario pagano, con ídolos de piedra protegidos. (Glassé, 2008: 302) 
Pero mitológicamente, la construcción de Kaaba se remonta a la era de Adán y Eva y, en algunas fuentes, incluso a antes de la creación de cualquier otra cosa en la Tierra. Como el Corán mencionó:

En verdad, la primera Casa establecida para la humanidad como bendición y guía es, sin duda, la de Bakka [Meca]. (Corán, 3:96)

Además, Al-Wasiti, atribuye este Hadiz al profeta Muhammad:

Meca es la ciudad que Alá exaltó, santificó y creó y estuvo rodeada de ángeles, mil años antes de crear cualquier otra cosa en la tierra. Luego se unió a Medina y unió Medina a Jerusalén y solo mil años más tarde creó [el resto del mundo] en un solo acto". (Armstrong, 2011: 261)

Al Baqir, el quinto Imam de Shia, va más lejos y afirma que Dios creó la Kaaba incluso antes de crear la Tierra y extendió la Tierra desde la huella de la Kaaba:

[Abu Hamza Al Sumaly] le dijo a Abu Ja'far [Imam Al Baqir, Quinto Imam de Shia] con respecto a la Sagrada Mezquita, ¿para qué lo llamó Alá como Al-Ateeq (El Antiguo)? '[...] Y dijo: Alá lo creó antes que las criaturas, luego Allah creó la Tierra después de ella, así que Él la extendió [la Tierra] desde debajo de [la Kaaba]. (Sadooq, 2017: Parte 3, 37)

Según las referencias míticas no islámicas, que mencionaban el origen de la Ciudad Santa de Meca y el santuario, el Asatir mencionó cómo Ismael y su hijo mayor Nebaota construyeron la ciudad de Meca.

Y después de la muerte de Abraham, Ismael reinó veintisiete años. $Y$ todos los niños de Nebaot gobernaron durante un año en la vida de Ismael. Y por treinta años después de su muerte desde el río de Egipto hasta el río Éufrates; y construyeron Meca. (Gaster, 1927: 262)

Al mismo tiempo, los eruditos musulmanes identifican el templo aludido en el Salmo 84:5-6, Baka, como el mismo Baka que está mencionado en el Corán e identifican a ambos como el templo de Meca, Kaaba.

¡Qué felices son los que de ti reciben fuerzas, y de todo corazón desean venir hasta tu templo! Cuando cruzan el valle del Llanto [Baka], lo convierten en manantial; hasta las Iluvias tempranas cubren el valle con sus bendiciones. (Salmos, 84:5-6)

En verdad, la primera Casa establecida para la humanidad como bendición y guía es, sin duda, la de Bakka. (Corán, 3:96)

De acuerdo con las creencias de los musulmanes y sus textos sagrados y la narración religiosa de la historia, la ciudad de Meca y su santuario se construyeron antes de la creación de cualquier ser humano, todo en el cosmos se creó en relación con esta ciudad y el viaje de Agar y su asentamiento en esta tierra sagrada revivió este paraíso perdido.

\subsection{La estructura y los componentes del santuario de Kaaba}

Kaaba estructuralmente es un simple edificio de piedra de granito cúbico, que alcanza aproximadamente quince metros de altura y sus lados miden diez por catorce metros. La base 
interior interior se encuentra a unos dos metros y veinte centímetros sobre el suelo. El techo está montado sobre tres pilares expuestos. El piso interior está hecho de mármol y piedra caliza. Una puerta dorada llamada Babut Taubah (Puerta del Arrepentimiento) en el lado derecho de la pared de entrada se abre a una escalera cerrada que conduce a una escotilla, que se abre al techo. Durante la mayor parte del año, la Kaaba está cubierta con una enorme tela de brocado negro, la Kiswah. Kiswah es una cortina negra de seda, bordada en oro con textos coránicos. (Wolff, 2017: 23)

En la esquina oriental es donde se encuentra Hajar al-Aswad, (la Piedra Negra). La esquina norte está orientada hacia Iraq, que se conoce como Ruknul-Iraqi (la esquina iraquí), la occidental como Ruknul-Shami, (la esquina Siria), y la sur como Ruknul-Yamani (la esquina Yemení). Las cuatro esquinas de la Kaaba apuntan aproximadamente hacia las cuatro direcciones cardinales de la brújula. Su eje mayor está alineado con el ascenso de la estrella Canopus hacia la cual se dirige su pared sur, mientras que las fachadas este-oeste se alinean aproximadamente con la salida del sol del solsticio de verano y la puesta de sol del solsticio de invierno.

El Hatim es un muro semicircular de noventa centímetros de altura en el lado noroeste de Kaaba. El espacio entre Hatim y Kaaba se llama Hijr Ismael (Sala de Ismael) porque allí se encuentran las tumbas de Ismael y Agar. Por lo tanto, muchos peregrinos, durante la circunvalación de Kaaba, amplían su círculo para incluir esta zona dentro de su órbita. (Lings, 2006: 10)

En el lado noreste de Kaaba, hay una estructura de vidrio y metal, que alberga una piedra Ilamada Maqam Ibrahim, que significa "La ubicación de Abraham".

\subsection{Sacralización y hierofanía del sitio}

Como cualquier otro fenómeno sagrado, no hay nada sobre Kaaba y el sitio que lo rodea que no haya sido envuelto en un relato de sacralización, desde su ubicación y orientación hasta las piedras que lo componen. Parece que cada elemento está participando de un plan sagrado para dirigir a la hierofanía, la manifestación de lo sagrado.

Rastreando mitos sobre los elementos de la Mezquita Sagrada y luego siguiendo los rituales realizados durante los ritos del Hajj, tratamos de identificar los roles que están designados para cada pieza en esta demostración divina de hierofanía.

Como la mayoría de los lugares sagrados de la tradición humana, se cree que el lugar donde se encuentra Kaaba es el centro del mundo; justo en frente de Baitul Ma'mur o la Casa Frecuentada en el cielo, donde los musulmanes creen que Eva y Adán se establecieron antes de su exilio en la Tierra (Tabataba'i, 1984: 171) "Figura 7".

Lo que no podemos ver es que dentro de la Kaaba hay tres pilares que sostienen el techo, al igual que los pilares invisibles mencionados en el Corán que sostienen la copa del cielo (Corán, 31:10). También hay una puerta llamada Babut-Tubah (Puerta del Arrepentimiento) abierta a una escalera, que conduce a la escotilla de la azotea. Se cree que este acceso al techo está directamente conectado con la entrada del cielo. 


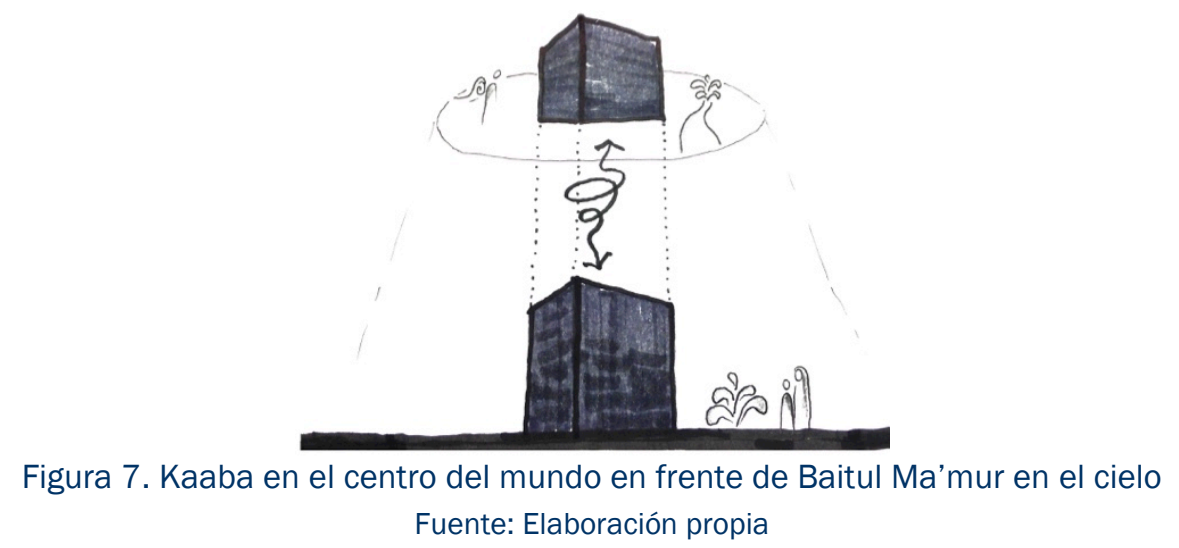

Sahih Al-Bujari narró de Malik bin Sasaa que Muhammad en la noche de su Miraj (Ascensión) oró en Baitul Ma'mur en el cielo, y todos los profetas anteriores y piadosos oraron detrás de él. Nuevamente, basado en este recurso, Baitul Ma'mur tiene una forma cúbica y está ubicado en el séptimo cielo. Y el arroyo de Kosar, el agua más sagrada del cielo, fluye delante de él. En realidad, según creencias islámicas, Kaaba es una metamorfosis terrenal del Baitul Ma'mur y el pozo Zamzam, la metamorfosis del arroyo celestial, Kosar. (Bujari, 2013)

Las tradiciones orales islámicas, Hadith, describen cómo Dios envió a Gabriel a la Tierra con una tienda celestial para hacer el primer refugio para Adán y Eva en el lugar sagrado de Kaaba y les enseñó el ritual del Hajj. Adán descendió del cielo al monte Safa y Eva al monte Marwa; Gabriel, por orden de Dios, los reunió y los refugió en el lugar de Kaaba y luego enseñó a Eva y Adán la circunvalación de Kaaba y Saay (esfuerzo) entre Safa y Marwa, imitando el acto de Agar en la búsqueda de agua para su hijo. Dios aclaró que la aceptación de este ritual y el sacrificio es una representación de su misericordia a pesar del pecado original y después de eso, permitiría que los padres de los humanos copulen allí y extiendan a sus descendientes sobre la tierra de Dios.

Alá el Alto se reveló a Jibraeel [Gabriel]: “SSoy Alá, el Beneficioso, el Misericordioso! Estoy siendo misericordioso con Adán y Hawwa [Eva], cuando ambos se quejaron ante Mí, por lo que se quejaron [por su soledad y privación del Cielo]. Entonces, desciende hacia ellos con una tienda de campaña desde las tiendas del Paraíso, así que estoy siendo misericordioso con ambos debido a su extraña naturaleza ambiental y su soledad. [...] Y Jibraeel hizo que Adán descendiera de Al-Safa, y Hawwa descendiera de Al-Marwa, y los reunió a todos en la tienda. [...] Y los rincones de la Casa Sagrada en la Tierra son (lo mismo que) el Bayt AlMamoor que está en el cielo '. [...] Entonces, Alá, bendecido y elevado Revelado para Jibraeel [...] levanta los cimientos de mi Casa, para Mis Ángeles y Mis criaturas de los hijos de Adán. [...] [Gabriel] alejó la tienda [...] levantó los cimientos de la Casa Sagrada, por una piedra de Al-Safa y una piedra de Al-Marwa, y una piedra de (Monte) Toor de Sinaí, y una piedra del monte Al-Salaam, que está en la parte posterior de Al-Kufa. (Sadooq, 2017: Parte 4, 22-24)

Luego él [Gabriel] fue con él [Adán] a la Casa -Kabah-. Así que le ordenó que circunvalase la Casa -Kabah- siete veces. Así que Adam hizo eso. Jibraeel le dijo: "Alá, el Bendito y el Altísimo te perdonó, y aceptó tu arrepentimiento, e hizo que tu esposa fuera permisible para ti". (Sadooq, 2017: Parte 3, 41) )(sic) 
Sobre la forma cúbica de Kaaba, Al-Hassan Ibn-Ali (segundo Imam de Shia) narra que su abuelo, el profeta Muhammad le narró:

¿Que a él [Muhammad] le preguntaron por qué el Kabah fue nombrado como Kabah? Entonces él dijo: 'Porque es cuadrado' Así que se le dijo: '¿Y por qué llegó a ser un cuadrado?' Él dijo: 'Porque la huella (Alineada en la parte inferior) de la Casa Frecuentada [Beit Al-Maamur] es cuadrada' Así que se le dijo: "¿Y por qué la Casa Frecuentada se convirtió en cuadrada?" Dijo: "Porque es por la huella del Trono, que es cuadrada". Así que se le dijo: '¿Y por qué el Trono llegó a ser cuadrada?' Él dijo: 'Porque las palabras en las que se basa Al-Islam son cuatro, y estas son: Gloria a Alá; la Alabanza es para Alá; no hay dios excepto Alá; y Alá es el más grande. (Sadooq, 2017: Parte 3, 36) (sic)

Según estas narraciones, la base de Kaaba está formada por rocas de Safa, Marwa, Sinai y Kufa, cuatro lugares en las cuatro direcciones cardinales respeto a Meca. Y la forma de Kaaba está simulando la forma del Trono de Dios.

Se cree que cuando Abraham e Ismael construyeron la pared y llegaron a una altura inalcanzable, Abraham trajo una piedra y se elevó sobre ella. Después de terminar la construcción, se subió a la piedra para dar un sermón a la gente, pero se cree que la piedra no pudo soportar esta acción sagrada y se derritió y tomó la forma de sus pies. Esta piedra, con una huella supuestamente humana, ahora se encuentra en el sur de Kaaba y se llama Maqam-Ibrahim (la ubicación de Abraham).

Sheik Sadugh narró del Imam Jafar Sadeq:

Abu Abdullah [Imam Al Sadiq, Sexto Imam de Shia] ha dicho: "Cuando Alá el Alto reveló a Ibrahim que debía llamar a la gente para el Hajj, tomó la piedra en la cual está el impacto de sus dos pies, y es el lugar destacado. Así que lo colocó en la base de la Casa -Kabah-, pegándose a la Casa -Kabah-, donde está hoy. Luego se puso de pie y gritó en voz alta, con lo que Alá el Alto le había ordenado. Así que cuando dio su sermón, la piedra no pudo soportarlo, así que sus pies se hundieron en ella. Entonces Ibrahim levantó los pies de la piedra. (Sadooq, 2017: Parte 2, 25-26) (sic)

En ella hay signos claros, [entre ellos] la morada de Abraham. Y quien entre en ella estará seguro. Dios ha ordenado a las gentes la peregrinación a la Casa, si disponen de medios. $Y$ quien reniegue (de su obligación y no realice la peregrinación, sepa que) Dios no necesita de nadie. (Corán, 3:97)

De acuerdo con el origen mítico de la Piedra Negra, en los textos islámicos, se menciona que cuando Dios privó a Adán y Eva del Cielo, descendió con ellos del paraíso, como un consuelo para su soledad, una piedra llamada Hajar-Al-Aswad (Piedra Negra), que ahora se encuentra en la esquina oriental de Kaaba. Se narra del profeta Muhammad:

Descendió del Paraíso más blanco que la leche, ipero los pecados de los hijos de Adán lo hicieron negro! (Lings, 2006: 3)

La piedra negra resucitaría el día del juicio con dos ojos y una lengua, y sería un testimonio de aquellos que sinceramente la tocaron y la besaron. (Ibn Hibban, 1984: 193) 
En realidad, sobre la base de estas narraciones islámicas, con respecto a la piedra de la ubicación de Abraham y la Piedra Negra, podemos ver la centralidad del Hombre en todo el cosmos para los musulmanes. Generalmente, en la narración de Abraham sobre la creación, el ser humano es la criatura más importante para Dios. Todos los universos son creados para servir a la creación del Hombre. Y especialmente en la narración islámica de la creación, toda la historia del hombre y los universos está dirigida a la gran misión de adoración que se realiza. Y nadie, ningún ángel, ninguna sustancia en todos los universos, sino el Hombre, puede soportar esta gran misión.

Ayer vi a los ángeles llamar a la puerta de la taberna medido y elaborado el barro utilizado para crear al Hombre los habitantes del reino del secreto y la pureza bebí copas de vino conmigo, la maravilla sin hogar el cielo no pudo soportar el peso de la responsabilidad así que, por suerte, el sorteo al azar cayó sobre mí [el Hombre], el loco (Poema de Hafez, Bly y Lewisohn, 2008:101)

Todos los espacios y todos los seres son seres sagrados para cumplir su misión. Pero algunos lugares son más sagrados debido a su función como mediadores para el cumplimiento de la misión sagrada. En este tipo de lugares sagrados, no hay nada que no siga una definición específica. Cualquier pieza individual tiene un papel mítico en este espectáculo de sacralización.

Dios le ordenó a Abraham que construyera la Casa en el lugar donde Eva y Adán, con Gabriel, habían construido el primer santuario, el cual, según las religiones abrahámicas, fue destruido durante el diluvio en la era de Noé. Más tarde, la familia de Abraham la construyó emulando a Baitul Ma'mur, el refugio original de los padres de los humanos en el séptimo cielo. A Abraham se le ordenó colocar la Piedra Negra, enviada desde el cielo, en la pared de la Kaaba.

Abraham impuso el orden sagrado al mundo profano de Agar. La mente religiosa no puede soportar estar suspendido en un cosmos profano caótico, más bien, es necesario que él esté en el centro de la misma y que esté en conexión directa con la fuente sagrado. El hombre religioso necesita organizar el mundo a su alrededor de la manera exacta en que el cosmos está organizado por el acto de la creación. (Eliade, 1959:36)

Abraham construyendo el santuario de Dios hizo un pacto con él. Le pidió a Dios que hiciera de esta ciudad un lugar seguro para sus descendientes, que los hiciera creyentes y les proporcionara productos básicos. Y Dios le ordenó que llamara a todos los creyentes a cumplir el ritual del Hajj, al igual que lo habían hecho Adán, Eva y Agar.

Y (recuerda) cuando Abraham dijo: "iSeñor mío! Haz esta tierra segura e impide que yo y mis hijos adoremos a los ídolos." (Corán, 14:35)

Y [recuerda] cuando establecimos la Casa [Kaaba] como un lugar de reunión y de seguridad para las gentes. "iTomad el sitio de Abraham como un lugar de oración!" $Y$ encargamos a Abraham e Ismael que purificasen Mi casa para los que la circunvalan y los que permanecen en ella en adoración y los que inclinan su cabeza y los que ponen su frente en el suelo.

$Y$ [recuerda] cuando Abraham dijo: "iSeñor mío! Haz esta tierra segura y provee de frutos a quienes de sus habitantes crean en Dios y en el Último Día." Dios dijo: "Y a quien no crea le 
permitiré disfrutar un poco y luego le arrastraré hacia el castigo del Fuego." iQué mal destino! Y [recuerda] cuando Abraham levantó los pilares de la Casa junto con Ismael [y suplicó]: "¡Señor nuestro, acéptanoslo! ¡En verdad, Tú eres Quien todo lo oye, Quien todo lo sabe!» (Corán, 2:125-127)

En verdad, a quienes no creen y ponen barreras para dificultar el acceso a la senda de Dios y a la Mezquita Sagrada, la cual dispusimos para toda la gente, tanto para los residentes como para los de fuera, y a quienes pretendan cometer en ella injusticia y opresión, les haremos probar del castigo doloroso. Y [recuerda] cuando dispusimos para Abraham el emplazamiento de La Casa: "No asocies nada a Mí y purifica Mi Casa para los que dan vueltas alrededor de ella, para los que permanecen en pie [rezando] y para los que se inclinan y prosternan." "Y llama a la gente a la peregrinación. Vendrán a ti a pie o en flacos camellos desde todo camino alejado. (Corán, 22: 25-27)

El pacto entre Abraham y Dios se hizo realidad. Dios hizo lo que Abraham le suplicó, hizo de Meca su santuario, un lugar para adorarlo, un lugar seguro y próspero en el que el hombre, su obra maestra, lo venerará siempre, desde Adán hasta los descendientes de Muhammad.

\section{Meca durante el tiempo de Muhammad}

Desde los primeros historiadores del Islam y los primeros viajeros al Medio Oriente, sabemos que la Meca también fue venerada antes del ascenso de Muhammad, y que el derramamiento de sangre y la guerra estaban prohibidos en su interior. La Meca era un oasis verde en el desierto de la Península Arábiga que brindaba un refugio seguro para los comerciantes que pasaban por la Ruta de la Seda. Y la Kaaba, el santuario pagano, fue venerada y dotada por creyentes de toda Arabia y de fuera de ella. El ascenso de Muhammad le otorgó una nueva vida como capital espiritual de millones de personas en todo el mundo.

Ibn Ishaq y Tabari, dos de los primeros y más importantes biógrafos de Muhammad, afirman que después de Ismael, su hijo Nabit, se hizo cargo del templo de la Kaaba. Posteriormente, la Kaaba paso a estar bajo la dirección de las tribus Yamani Jurhumities, la tribu de la esposa de Ismael y los primos de los hijos de Ismael. Los descendientes de Abraham no disputaron su autoridad ya que la segunda esposa de Ismael pertenecía a estas tribus. Tenían autoridad sobre Meca, la Kaaba y la peregrinación hasta que Qusayy, de la tribu Quraysh, una rama de los hijos de Ismael, se acercó a ellos, con miembros de la tribu Quraysh, que decían: "Tenemos más derecho que ustedes a ejercer esta autoridad". La derrota de Jurhumities a manos de Qusayy hizo que estos asumieran la autoridad sobre ciudad sagrada. Pero Jurhumities llenaron el pozo Zamzam en el momento en que huyeron de Meca. (Guillaume, 1998: 52)

Ibn Ishaq nos informa de que el comienzo del culto a la piedra y de la idolatría entre la gente de Meca nació cuando el número de residentes aumento y fueron obligados a emigrar. Los emigrantes que salían de la ciudad se llevaron una piedra del área sagrada. Dondequiera que se establecieron, la instalaron y la circundaron de la misma manera que solían hacer con la Kaaba. A medida que las generaciones cambiaron, olvidaron la función simbólica de esas piedras y las adoraron como si fueran ídolos. Sin embargo, aún conservaban algunas tradiciones de su fe original, como la peregrinación a la Kaaba. Así que volviendo a Meca, introdujeron sus ídolos en la Kaaba como regalos. De ahí que la Kaaba se convirtió en una casa de ídolos árabes. Ibn Ishaq afirma que a pesar de esto reconocieron la superioridad de la Kaaba como el templo y la mezquita de Abraham. (Guillaume, 1998: 35-36) 
La promesa que Dios hizo a Agar se hizo realidad. Su descendencia aumentó enormemente y la cantidad de peregrinos que honraron el santuario, advocándola a ella, se hizo incontable. Los peregrinos que venían de visita desde todas partes de Arabia y más allá traían continuamente valiosos regalos a Meca. Y los ritos les enseño una vez el Ángel de Dios a Eva y Adán, y luego a Agar y Abraham, continuaron siendo realizados con entusiasmo por peregrinos de toda la Península Arábiga y de fuera de ella.

Sin embargo, el pozo Zamzam fue enterrado y olvidado por la gente de Meca hasta que fue rerevelado a Abd al-Muttalib, el abuelo del profeta Muhammad. Estaba durmiendo la siesta en el interior de Hijr-lsmael, el lugar donde está enterrada Agar, cuando una figura sombría se le acerca y le dice:

"Cava la claridad dulce". "¿Qué es la claridad dulce?" Preguntó, pero el orador desapareció. [...] El visitante regresó y dijo: "Cava beneficencia". Pero una vez más su pregunta no recibió respuesta. La tercera noche le dijeron: "Cava el tesoro atesorado", y una vez más el orador desapareció en su interrogatorio. Pero la cuarta noche la orden fue: "Cava Zamzam"; y esta vez cuando dijo: "¿Qué es Zamzam?" el orador dijo:

"Cávala, no te arrepentirás,

Porque ella es tu heredad.

De tu mayor antepasado.

Ella nunca se secará, ni fallará.

Para regar a toda la multitud de peregrinos ". (Lings, 2006: 10)(sic)

Durante la era pagana de Meca no se toleraba la violencia ni el derramamiento de sangre dentro de sus fronteras. Cualquiera que hiciera mal sería expulsado. Las tribus árabes consideraban a Meca como un santuario seguro, lo que la convirtió en un refugio lejos de las incesantes guerras tribales y dio como resultado el éxito comercial de la Ciudad Santa. Se creía que si un rey intentaba tratarla sin respeto, insultándola o paganizándola, moriría en el instante y se creía que no existía un ejército en todo el mundo que pudiera derrotarla.

Ahora el Tubba [un rey yemení] y su gente eran idólatras. Cerca de Meca, en el camino hacia el Yemen, [...] los hombres del Hudhayl (una tribu) [...] se acercaron a él y le dijeron: 'Oh rey, ¿no podemos llevarte a un antiguo tesoro que los antiguos reyes han pasado por alto? Contiene perlas: topacio, rubies, oro y plata. Ciertamente, dijo él, y agregaron que era un templo en Meca que sus gentes adoraban y donde rezaban. Pero la verdadera intención de los Hudhaylis era destruirle, ya que sabian que cualquier rey que lo tratara con falta de respeto seguramente moriría. (Lings, 2006: 8) (sic)

Muhammad nació en el año del Elefante, aproximadamente 570 d.C., el año en que Abraha, el rey cristiano yemení, marchó sobre la Kaaba y Meca con un gran ejército. Se dice que los elefantes del ejército se negaron a ingresar a la ciudad y aparecieron nubes oscuras de pájaros que se estrellaron contra Abraha y todas sus tropas lanzando azufre.

y envió sobre ellos pájaros en bandadas sucesivas que les lanzaron piedras de barro, que les dejaron como heno masticado (Corán, 105:3-5)

En la época de la juventud de Muhammad, la mayoría de los ciudadanos de Meca eran paganos y Kaaba estaba dedicada a la deidad nabatea Hubal. Muhammad, apoyado por su rica esposa 
Khadija, se convirtió en un famoso comerciante en su tierra natal y estuvo en contacto con personas de diferentes culturas a través de sus viajes comerciales en compaña de su tío AbuTaleb. Visitó a personas cristianas, judías, indias y también iraníes. Es probable que todos le transmitieran sus propios mitos. Muhammad se sintió profundamente atraído por la leyenda de Abraham y Adán sobre la construcción de la Kaaba. Se dice que él, como su abuelo, solía pasar mucho tiempo en el sitio de la Kaaba y particularmente en Hijr Ismael, donde está enterrada Agar.

Muhammad recibió su primera revelación en 610 d.C., el mismo año en que el rey Khosrow II invadió el territorio bizantino. Recibió el primer Ayat (Símbolo) del Corán en Jabal-al-Nour (Montaña de la Luz) dentro de la cueva de Hara, donde solía pasar tiempo meditando.

Recita en el nombre de tu Señor, el Cual ha creado. (Corán, 96:1)

Cuando bajó de la montaña, el primero que respondió a su llamadoa al Islam fue su esposa Khadija. Los jefes tribales de Meca no estaban preparados para aceptar un ataque tan radical contra sus valores, y por lo tanto lo disputaron severamente. En consecuencia, los primeros creyentes se encontraban entre las personas desfavorecidas de la sociedad, como las mujeres y los esclavos.

Lo primero que había hecho Muhammad, después de tomar el poder sobre Meca en 630 d.C., fue orar en el sitio de la Kaaba y hacer la circunvalación; luego bebió del pozo Zamzam y ordenó que desaparecieran los ídolos de la Kaaba. Anunció a Meca como un lugar seguro y sagrado de Alá, concedió el perdón a todas las autoridades de Meca y les prometió la prosperidad de Meca, asegurándoles que traería peregrinos y riquezas a la ciudad. Él reconectó su poder con el poder establecido previamente.

Juro por la higuera y el olivo y por el monte Sinaí y por esta ciudad segura que, ciertamente, hemos creado al ser humano en la mejor condición. Luego, le hemos relegado a lo más bajo de lo bajo (Corán, 95: 1-5)

Muhammad restableció el ritual del Hajj según la tradición de Abraham. Desde entonces, los habitantes de Meca paganos habían contaminado el ritual del Hajj con algunos ritos extraños, como los ritos Hums. Ibn Ishaq informa que alrededor del año del elefante Quraysh inventó la idea de los Hums y la puso en práctica. Los habitantes de Meca dijeron: "Somos los hijos de Abraham, la gente del territorio sagrado, los guardianes del templo y los ciudadanos de Meca. Ningún otro árabe tiene derechos como los nuestro o una posición como la nuestra. Somos la gente del santuario."(Guillaume 1998: 88) Así que inventaron reglas tabú llamadas Hums. Por ejemplo, obligaron a los otros árabes a que hicieran desnudos la circunvalación a la Kaaba.

Los hombres iban desnudos, mientras que las mujeres se cubrían con una túnica abierta ya sea por delante o por detrás. Una mujer árabe que iba por la Casa dijo así:

Hoy en día se puede ver todo o parte de mi cuerpo, ipero lo que se puede ver no lo considero propiedad común! (Guillaume, 1998, 88)

Muhammad abolió los Hums y pidió el Hajj según las reglas establecidas por Dios. Él restableció el Ritual del Hajj de la misma manera que lo hicieron Agar y Abraham, siguiendo el ritual de Adán y Eva. Llamó a todos los musulmanes dondequiera que vivieran para realizar dicho Ritual al menos 
una vez en la vida si física y económicamente estuvieran capacitados. Revalidó la sacralidad y la seguridad de Meca y lo convirtió en el lugar más sagrado para los musulmanes hasta hoy en día.

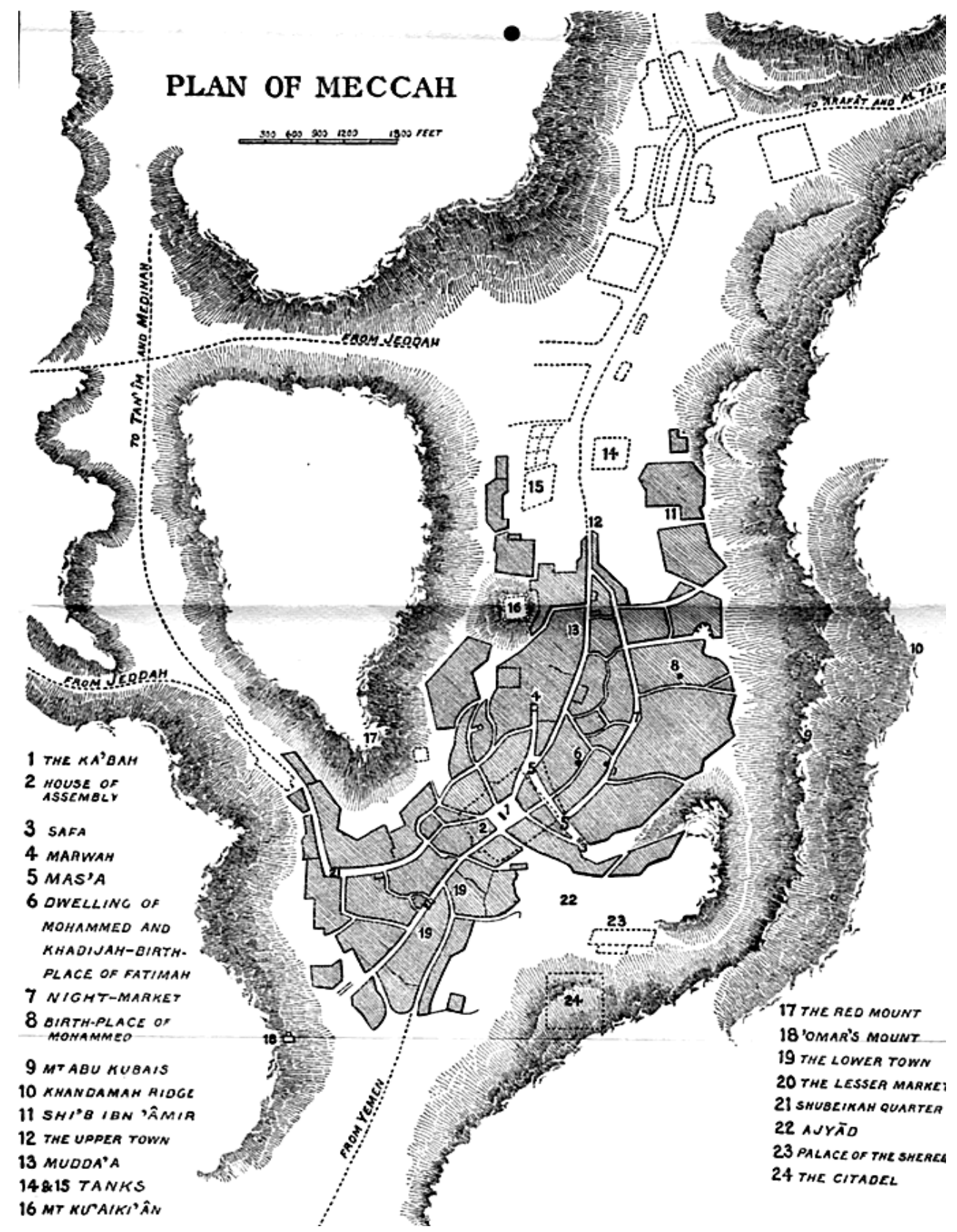

Figura 8. Plano de la Meca Vieja

Fuente: Mohammed and The Rise of Islam, 2003 


\section{Meca en el tiempo del Hajj}

Los rituales revelan valores en su nivel más profundo ... los hombres expresan en el ritual lo que más los mueve, y dado que la forma de expresión es convencional y obligatoria, son los valores del grupo los que se revelan. Veo en el estudio de los rituales la clave para comprender la constitución esencial de las sociedades humanas. (Wilson, 1954: 241)

El ritual del Hajj como cualquier otro ritual tiene aspectos muy teatrales. Siguiendo los términos de Mónica Wilson, en el Hajj uno puede rastrear las intenciones más profundas dentro de la civilización islámica, intenciones que se hacen visibles en la ciudad de Meca, a través del lenguaje simbólico del teatro.

Los participantes de este teatro experimental, los Hajies, parten de los Miqats, es decir, cinco puntos fijos diferentes en la Península Arábiga, donde los peregrinos aterrizan dependiendo del origen de su vuelo, ya que no hay ningún vuelo directo desde el extranjero a Meca.

Los actores deben vestirse con la prenda Ihram (prohibición) cuando llegan a la frontera de Miqat. La ropa Ihram está hecha con un material blanco liso como el de Kafan (la mortaja), el vestido que cubre cadáveres para la ceremonia del entierro islámico.

En la tierra previa a la etapa de Miqat, el actor se entrega a su nuevo estado como un ser puro, como una vida desnuda. El actor se somete al tabú. A partir de este momento, se le prohíbe cuidar de su cuerpo. Su cuerpo deformado en Kafan, debe ser olvidado durante la actuación del Hajj. En consecuencia, a Haji se le prohíbe mirar el espejo, cortarse el cabello o las uñas, oler perfume, maquillaje así como hacer el amor, etc.

Además, está prohibida cualquier cosa que afecte sobre el cuerpo del otro. Se le prohíbe dar ordenes a cualquiera, cazar, dañar a cualquier ser vivo, fluir sangre, etc.

Miqat es el backstage donde, en términos de Agamben, las "vidas desnudas" quedan excluidas de otras formas de vida (Agamben, 1998), la vida desnuda del Hajjis se integraría en el "estado de excepción" del Drama Divino del Hajj (Shari'ati, 2015: 35 ).

Ahora el Hajji, repudiando cualquier afecto sobre su cuerpo y sobre cualquier otro cuerpo, pasa a la siguiente etapa, la Kaaba, donde con millones de otras "vidas desnudas" debería rodear la caja vacía de la Kaaba ubicada en el centro del mundo. Giran siete veces en sentido contrario a las agujas del reloj, alrededor de este punto negro fijo de la Kaaba, que es el umbral entre la tierra de los hombres y la tierra divina.

Los cuerpos no-cuerpos del Haji se mueven juntos como una amalgama de cadáveres caminantes. Los actores se entrelazan con otros cuerpos, todos envueltos holgadamente en un disfraz de muerte, repitiendo este círculo de meditación siete veces, ensayando su papel como seres no corporales. Los actores sin cuerpo del Hajj practican el ritual para trascender a un estado puro sin cuerpo, para estar preparados al ingreso en la siguiente etapa, la etapa de Agar en su búsqueda de agua. 


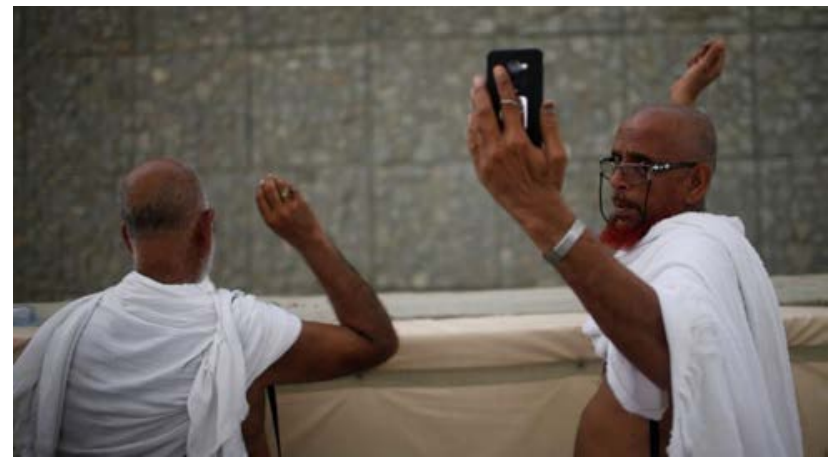

Figura 9. Muslim pilgrims cast stones at Satan Pillar, Saudi Arabia, 2017 Fuente: REUTERS/Suhaib Salem, 2017

En este Tawaf (circunvalación), los actores del Hajj deben incluir a Al-Hijr, donde está enterrada Agar. Tawaf, el acto más simbólico de este espectáculo divino, incluye la circunvalación alrededor de la Casa de Dios y la tumba de Agar. Los peregrinos deben rodear y venerar el cuerpo de Agar, la madre de la nación, la fundadora de Meca y la que proporcionó agua para su pueblo, junto con Dios “Figura 10".

En la siguiente etapa, los actores deben interpretar la pieza de Saay (esfuerzo) entre dos montañas de Safa y Marwa, deben trotar este camino siete veces como Agar buscó agua "Figura 11". Luego beberían un poco de agua de pozo Zamzam, el avatar del arroyo celestial de Kosar.

Ciertamente, algunos de los ritos de Dios son en Safa y Marwa. Por tanto, quién peregrine a la Casa de Dios o la visite, no comete pecado yendo de una a otra. Y quien haga el bien voluntariamente, sepa que, ciertamente, Dios es agradecido, sabio. (Corán, 2:158)
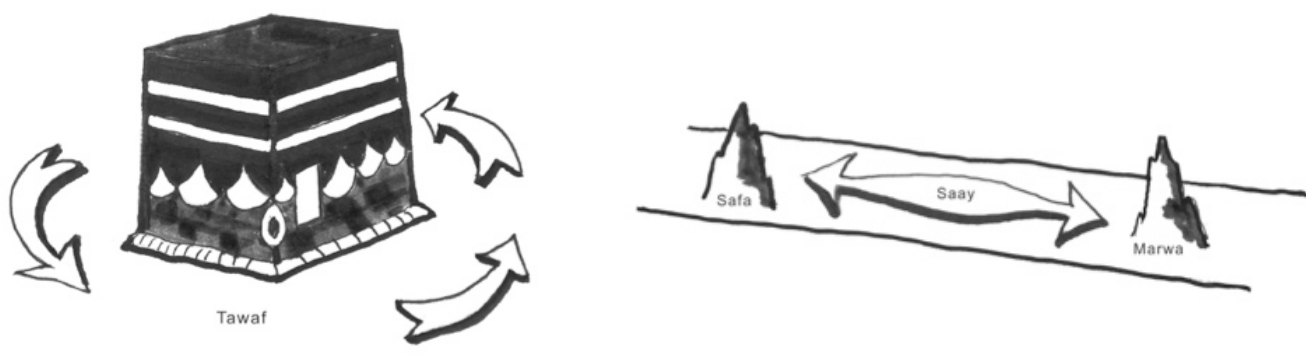

Figura 10. Tawaf - circunvalación (derecha) y Figura 11. Saay - esfuerzo (izquierda)

Fuente: Elaboración propia

Pasarán el resto del día y de la noche rezando en la llanura de Mina (amor).

Posteriormente, los actores salen de Meca a Arafat (Conocimiento). Arafat es una llanura desértica a unos veinte kilómetros al sureste de Meca, donde se encuentra Jabal-al-Rahman (Monte de la Misericordia), el lugar donde Muhammad dio su sermón de despedida. En el desierto del Conocimiento, los actores tienen tiempo hasta la puesta del sol para concentrarse en su papel y en el concepto principal del Drama Divino. 
El desierto del Conocimiento debe ser abandonado antes del atardecer. Los actores deben apresurarse para la nueva etapa, Mahsaar (Conciencia). Pasan toda la noche en el plano de la conciencia, rezando. Deberán recolectar setenta piedras de la Tierra de la Conciencia.

La peregrinación mayor se lleva a cabo en meses determinados. Por tanto, quien se proponga realizar la peregrinación mayor en ellos, que no mantenga relaciones sexuales, ni peque, ni dispute durante ella. El bien que realicéis, Dios lo sabrá. Y tomad provisiones, pero, desde luego, la mejor provisión es el temor de disgustar a Dios. Así pues, iTemed disgustarme! ¡Oh, los dotados de discernimiento! (Corán, 2:198)

La tropa sin cuerpo de Alá debería estar en la frontera de la llanura de Mina (Amor) al amanecer. Aquí, al estar totalmente involucrado en su papel y totalmente alejado de su cuerpo, el Haji debería prepararse para el gran sacrificio. Al igual que Abraham, ella/él debería derrotar a Satanás para prepararse para la misión divina del sacrificio. El Haji debe apedrear el pilar de Satanás ubicado en Mina siete veces por piedras que ha recogido de la llanura de Mashaar. Ahora ella/él está listo para sacrificarse por Dios, el director del drama. Pero al sacrificar un animal, el Haji está afectando el cuerpo de otro, así que ahora la ropa de Ihram no es válida y debería quitársela y cortarse el cabello. Ahora ella/él regresa a su ser corporal. Zoe y Bios deberían reunirse de nuevo. El estado no corporal caduca y la vida continúa de nuevo. El espectáculo culmina haciendo el último Tawaf, Tawaf al-Wadaa (Circulación de despedida).

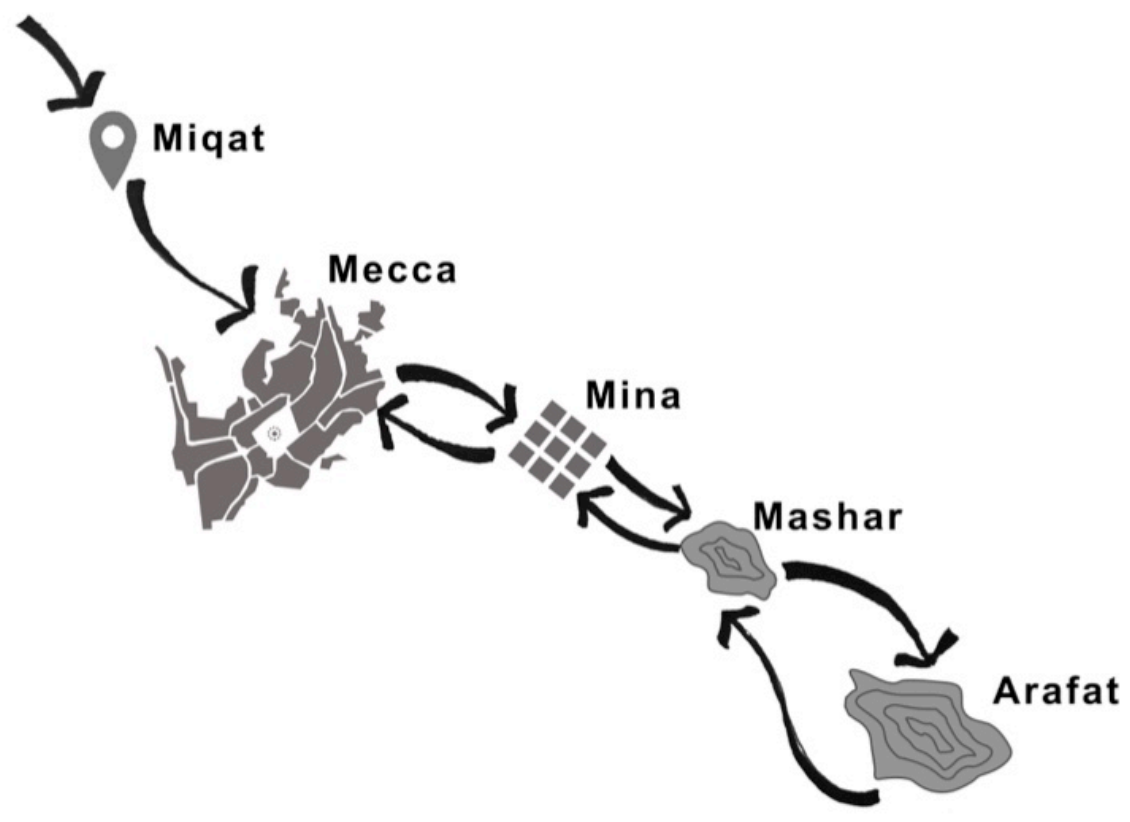

Figura 12. El diagrama del Hajj

Fuente: Elaboración propia

La ciudad de Meca se construye en base y al servicio de esta sacralidad abrumadora venerada por el ritual del Hajj. No hay ningún elemento del santuario ni de su entorno que no esté sacralizado. Cada parte de la ciudad está trabajando al servicio del ritual del Hajj para llevar a cabo el mensaje del espectáculo Divino, la manifestación de lo sagrado. Y los distritos residenciales que no forman parte de la actuación deben estar estrictamente separados de las escenas. En realidad, aplicando los términos de Goffman, el teatro del Hajj se construyó sus “outsiders” (Goffman, 1974). 
Los residentes nativos de Meca pasan a ser los forasteros del Show, los Hajis son sus artistas y el mundo no musulmán forma la audiencia. Los forasteros se benefician de los ingresos económicos del programa, pero deben estar separados de los actores, para evitar cualquier interferencia no planificada en el programa, ya que siempre hay muchos secretos oscuros que deben ocultarse, como las causas de la estampida durante el Hajj de 2015.

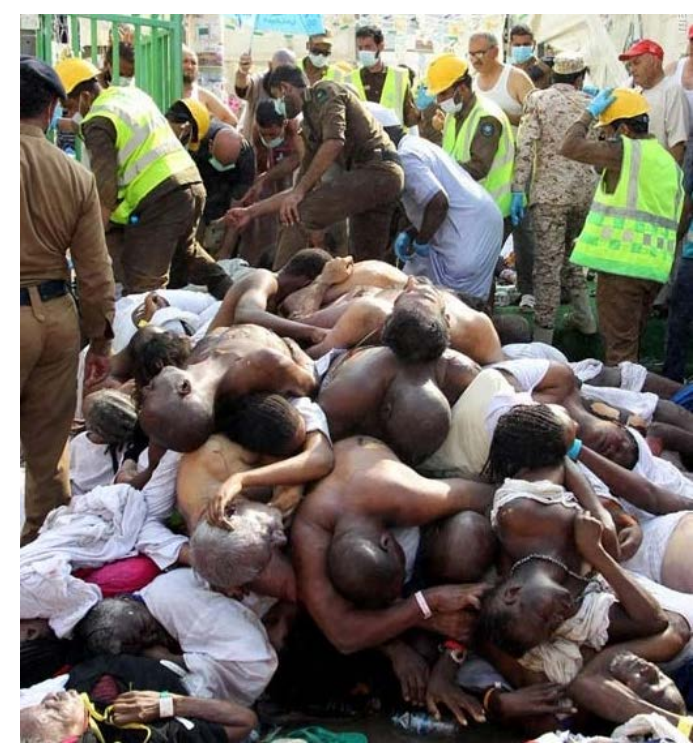

Figura 13. A stamped killed over 2,000 people during 2015 Haj Fuente: AFP PHOTO / STRSTR/AFP/Getty Images, 2015

\section{Conclusión}

Cuando Dios creó a Adán, le advirtió sobre el fruto prohibido:

pero no del árbol del conocimiento del bien y del mal. Si comes de ese árbol, te juro que morirás". (Génesis, 2:17)

Eso es mentira. No morirán. Dios bien sabe que, cuando ustedes coman del fruto de ese árbol, serán iguales a Dios y podrán conocer el bien y el mal. [...] Por eso Dios los expulsó del jardín de Edén, y puso al hombre a cultivar la tierra de donde había sido formado. (Génesis, 3: 4-5, 23)

Dijimos. "iOh Adán! Habitad tú y tu pareja en el Jardín y comed ambos de él cuanto y donde queráis, pero no os acerquéis a este árbol, pues entonces seríais de los transgresores." Pero Satanás les engañó a ambos y les sacó de aquello en lo que estaban. Y Dijimos: "iDescended! Seréis enemigos unos de otros. La Tierra será para vosotros una morada y lugar de disfrute por un tiempo. (Corán, 2: 35-36)

Agar ha sido expulsada por sus amos de la seguridad y el santuario de la casa, de la familia y de la tribu, para que no tuviera derecho a la herencia que le correspondía a su hijo. Es entonces cuando desciende al desierto de Paran.

Entonces [Sara] fue a decirle a Abraham: "Echa de aquí a esa esclava y a su hijo; él [Ismael] no tiene derecho a compartir la herencia con tu hijo Isaac". (Génesis, 21:10) 
Si leemos estas líneas como mitos, en lugar de textos sagrados o incluso narraciones históricas, podemos rastrear una idea central que se repite en la mitología humana; una persona en el poder, a quien le advierten de que un bebé, con el tiempo, le robará su poder, tratará de deshacerse de él. Pero la madre naturaleza tratará bien a este niño y lo devolverá al poder. Que los recién creados, Adán y Eva, comieran del fruto prohibido, suponía un peligro, el de saber lo que Dios sabe y, en consecuencia, llegar a ser como el dios, así que Dios los mandó al exilio a la Tierra, donde construyeron la civilización humana.

Eva y Agar, ambas expulsadas violentamente de un paraíso, han construido su propio paraíso. Ambas marginadas del trono de Dios, construyeron su propia ciudad, como consecuencia de su separación de la divinidad y como consecuencia de su pecado.

Agar, esta mujer incrédula, que ha dejado su tierra natal y sus ídolos nativos en busca de un nuevo carácter sagrado en la tienda de Abraham y Sara, de repente se encuentra como carne humana, un útero para la voluntad caprichosa de Dios de dar el Niño prometido a su profeta Abraham. Así, ella huye de la tienda sagrada de Abraham al desierto profano, pero Dios la hace regresar con sus amos hasta que la echen. Echada de nuevo, en la tierra profana, encuentra su paraíso profano fuera de la visión de cualquier Dios. Sí, San Agustín tenía toda la razón, Agar personifica la ciudad terrena; la ciudad de Eva también fue la tierra.

No obstante, Abraham, por mandato de Dios, regresa para imponer lo sagrado en el mundo terrenal profano de Agar. La ciudad de Agar es agua y refugio. Agua y refugio para ella, su hijo y sus ovejas, pero Abraham impone lo sagrado a la ciudad de Agar. Abraham es el hombre de Dios, el hombre religioso, por lo que su ciudad debe ser la ciudad de Dios. La ciudad de Dios debe ser un reflejo del cielo, todo debe ser un símbolo de la tierra divina. Para el hombre religioso, todo debe estar en orden como el cosmos, y para él la fundación de la ciudad, similar al acto de creación, pone fin al caos del reino profano (Eliade, 1959). Una vez que se crea el mito de Agar, Abraham lo confiscó para rastrear su santuario en la profana ciudad terrenal de refugio de Agar.

Gilead, la ciudad apocalíptica de Atwood (Atwood, 1998), es un buen ejemplo de la ciudad de Dios, la ciudad de Dios Todopoderoso y Omnipresente, en la que todo está perfectamente separado y dividido. Especialmente, esta división es visual, para crear tipos de espacios transparentes, cristalinos y jerárquicos que enfaticen la visibilidad y la simplicidad al servicio de Dios como un poder masculino. Gilead es el paraíso de Dios omnipresente. La contra-imagen de esta bien controlada Gilead es la Gilead de Offred, en sus recuerdos fragmentados, cuando aún era June. Gilead en la imaginación de June es una ciudad compleja, multicolor, multicapa, multidireccional y multiplex. La ciudad de June es una multiplicidad, en la que uno puede volverse invisible, puede "devenir en todo" "pasar desapercibido" (Deleuze \& Guattary 1987: 279-280) para hacer lo que él desea, para cometer pecado y, en resumen, para ser libre. Y también, es en esta ciudad de complejos múltiples, donde uno puede volverse individual. En esta ciudad múltiple de Eva, Agar y June es donde el individuo puede volverse Anómalo, el anómalo que establece el borde de la multiplicidad, el ser que puede cambiar "la línea de fuga" y el individuo que supone "la condición previa para la alianza necesaria para devenir" (Deleuze \& Guattary 1987: 249). Eva, Agar y June son hechiceras anómalas que se atreven a volar más lejos de los límites de los estándares patriarcales establecidos. Su ciudad es de una complejidad que reconoce y promueve tanto la individualidad como el compromiso social. 
La ciudad de Eva, Agar y June es una ciudad minoritaria en el sentido deleuziano. En este sentido, devenir minoritario no es una cuestión de cantidad, de la misma manera que ser mayoría tampoco implica número, sino "un estado de dominación". Por ejemplo, ser mayoritario masculino es una cuestión de "saber cómo 'el hombre' constituía un estándar en el universo en relación con el cual los hombres forman (mayoritariamente) una mayoría". Convertirse en minoritario, siempre pasa por ser mujer, igual que "las mujeres deben convertirse en ... mujer "(Deleuze \& Guattary 1987: 291). La ciudad de Agar, fuera de los estándares impuestos por Dios/Hombre/Mayoría, es una mujer que se deviene mujer. Ser Eva, Agar y June, en su esencia, es devenir-mujer.

La ciudad islámica, en su origen, es una ciudad hecha por y para Agar, la mujer esclava, exiliada y marginada. En otras palabras, la ciudad y la civilización islámicas, en su germen, han sido formadas por y para las minorías en el proceso de "devenir-minoritario". Las clases vulnerables de la sociedad como las mujeres, los esclavos, y las marginadas, construyeron su devenirrefugio/ciudad, fuera del alcance del poder mayoritario establecido. Siguiendo la idea de Gilles Deleuze y Félix Guattari, se puede decir que la formación de la ciudad islámica, tuvo una intención de "devenir-mujer", "devenir-minoritario" y "desterritorialización" de la mayoría patriarcal (Deleuze y Guattari, 1987: 291). La ciudad islámica ha sido escenario de un proyecto revolucionario de las minorías, impulsado por Muhammad, pero que, como cualquier otra revolución, a lo largo de la historia humana, ha sido traicionada y confiscada por el poder mayoritario. 


\section{Referencias}

AL-AZMEH, A. (1993): Islams and Modernities. Nuevo York, EE.UU.: Verso.

AGAMBEN, G. (1998): Homo Sacer: Sovereign Power and Bare Life. Stanford, EE.UU.: Stanford University Press.

APTER, D. E. (2006): Politics as theatre: an alternative view of the rationalities of power. En J. C. Alexander, B. Giesen, J. L. Mast. (Ed.), Social Performance: Symbolic Action, Cultural Pragmatics, and Ritual, (pp. 218-256), Nuevo York, EE.UU.: Cambridge University Press.

ARMSTRONG, K. (2011): Jerusalem: One City, Three Faiths. Nuevo York, EE.UU.: Random House Publishing Group.

ATWOOD, M. (1998): The Handmaid's Tale. Nuevo York, EE.UU.: Anchor.

AUGUSTINE, S. (2008): The City of God. Massachusetts, EE.UU.: Hendrickson Publishers.

BAZARJANI, N. (2016): Espacio público: conflicto y poder en la ciudad de Teherán. Cuadernos de investigación urbanística. (108), p. 1-70.

BIANCA, S. (2000): Urban Form in the Arab World: Past and Present. Londres, Inglaterra: Thames \& Hudson.

BLY, R. et LEONARD, L. (2008): The Angels Knocking on the Tavern Door: Thirty Poems of Hafez. Nuevo York, EE.UU.: HarperCollins Publishers.

BUKHARI, M. (2013): Sahih Al-Bukhari: The Early Years of Islam. Translated by Muhammad Assad. Nuevo York, EE.UU.: The Other Press.

DALY, M. (1985): Beyond God the father: Toward a philosophy of women's liberation. Bostón, EE.UU.: Beacon Press.

D'ANDREA, D. (2011): The World in Images. Subjectivity and Politics in Max Weber. Humana.Mente Journal of Philosophical Studies, Vol. 18, pp. 87-104.

DELEUZE, G. et GUATTARI, F. (2005): A Thousand Plateaus: Capitalism and Schizophrenia. (5th ed.) Londres, Inglaterra: University of Minnesota Press.

ELIADE, M. (1959): The Sacred and the Profane: The Nature of Religion. Boston, EE.UU.: Houghton Mifflin Harcourt.

FIERO, G. (2015): The Humanistic Tradition, Volume I, Prehistory to the Early Modern World. (7th ed.) Nuevo York, EE.UU.: McGraw-Hill Higher Education.

FIRESTONE, R. (1992): "Abraham's Journey to Mecca in Islamic Exegesis: A Form-Critical Study of a Tradition." Studia Islamica, (76), pp. 5-24.

FIRUZABADI, M. (1992): Tanwir Al-Miqbas Min Tafsir Ibn Abbas. Beirut, Líbano: Dar al-Kutub al-IImiyya.

GASTER, M. (1927): The Asatir: The Samaritan Book of the Secrets of Moses. Londres, Inglaterra: Royal Asiatic Society.

GLASSÉ, C. (2008): The New Encyclopedia of Islam. Maryland, EE.UU.: Rowman \& Littlefield. 
GOFFMAN, E. (1974): Frame Analysis: An Essay on the Organization of Experience. Cambridge, EE.UU.: Harvard University Press.

GUILLAUME, A. (1998): The Life of Muhammad, a Translation of ISHAQ'S Sirat Rasul Allah. Karachi, Pakistan: Oxford University Press.

IBN HIBBAN, M. (1984): Sahih Ibn Hibban Vol. 2. Beirut, Líbano: Mu'assasah al-Risalah.

KAHF, M. (2016): Hagar Poems. Arkansas, EE.UU.: University of Arkansas Press.

KHALDUN, I. (1958): The Muqaddimah. Princeton, EE.UU.: Princeton University Press.

LÉVI-STRAUSS, C. (2013): Myth and Meaning. Londres, Inglaterra: Routledge.

LINGS, M. (2006): Muhammad: His Life Based on the Earliest Sources. (5th ed.) Rochester, EE.UU.: Inner Traditions/Bear.

LOCKYER, H. (1967): All the Women of the Bible. Michigan, EE.UU.: Zondervan.

MARGOLIOUTH, D. (2003): Mohammed and the Rise of Islam. Nuevo York, EE.UU.: The Knickerbocher Press.

MASSEY, D. (2005): For space. Londres, Inglaterra: SAGE Publications Ltd.

SADOOQ, S. (2017): Illal Al-Sharaie: Reasons for Islamic Practices, Volume 2. California, EE.UU.: CreateSpace Independent Publishing Platform.

SHARI'ATI, A. (2015): Hajj. California, EE.UU.: Evecina Cultural \& Education Foundation.

TABATABA'I, S. (1984): Al-Mizan Fi Tafsir Al-Quran, Volumen 8. Qom, Iran: Isma'iliyan.

WEBER, M. (1946): From Max Weber: essays in sociology. Nuevo York, EE.UU.: Oxford University Press.

WILSON, M. (1954): Nyakyusa Ritual and Symbolism. American Anthropologist 56 (2), pp. 228-241.

WOLFF, A. (Ed.). (2017): The Islamic World to 1041, the Britannica Guide to Islam. (illustrated ed.) Nuevo York, EE.UU.: The Rosen Publishing Group, Inc,.

"Bible, Traducción en lenguaje actual. (TLA)", (Nov 14, 2018). Recuperado de https://www.biblegateway.com

"Code of Hammurabi." Encyclopædia Britannica Inc, (Nov 14, 2018). Recuperado de http://Hammurabi.com.

"Quran.", accessed (Nov 14, 2018). Recuperado de https://al-quran.info/. 